

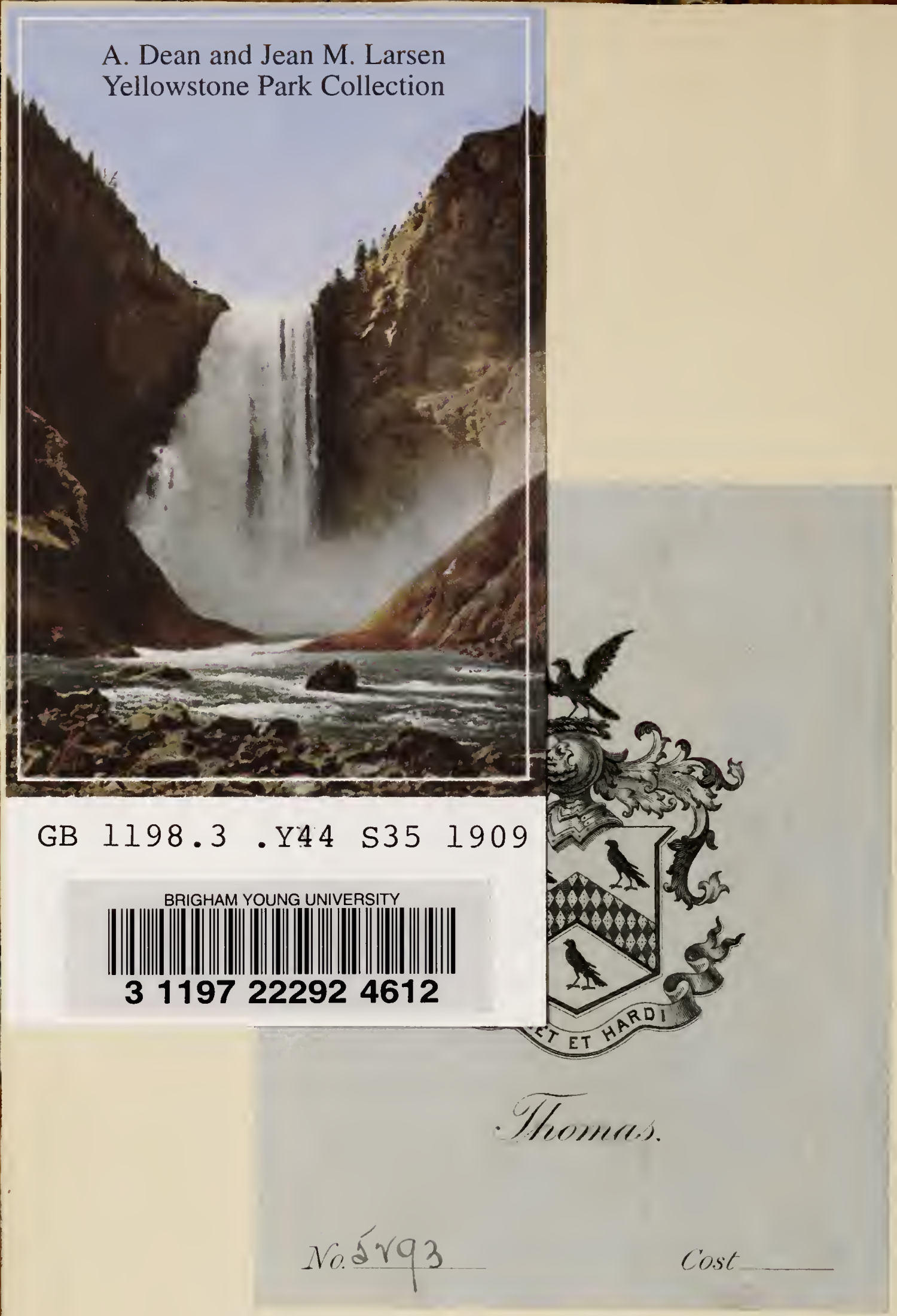


Digitized by the Internet Archive in 2013 



DEPARTMENT OF THE INTERIOR

UNITED STATES GEOLOGICAL SURVEY

GEORGE OTIS SMITH, DIRECTOR

\section{BULLETIN 395}

\section{RADIOAGTIVITY OF THE THERMAL WATERS}

\section{OF YELLOWSTONE NATIONAL PARK}

BY

HERMAN SCHLUNDT

AND

RICHARD B. MOORE

WASHINGTON

GOVERNMENT PRINTING OFFICE

1909 


\section{hes $=48$}

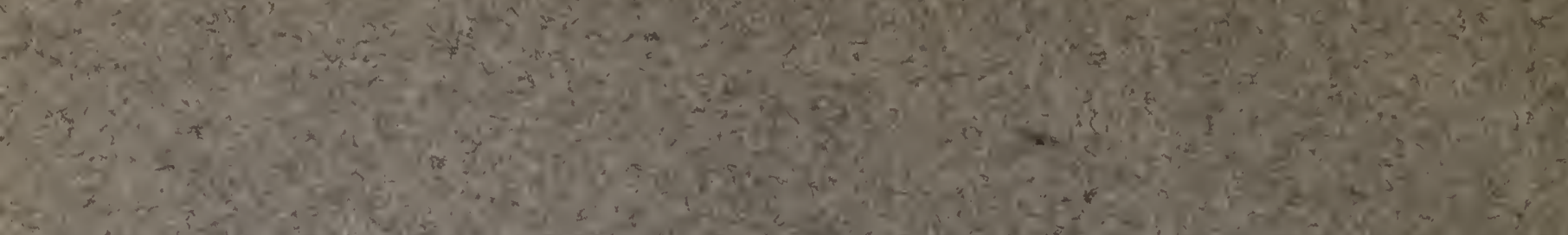
(3)

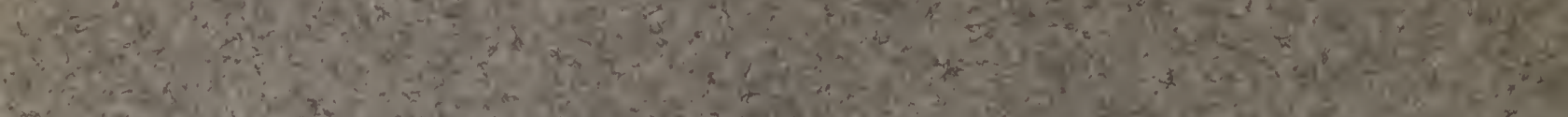

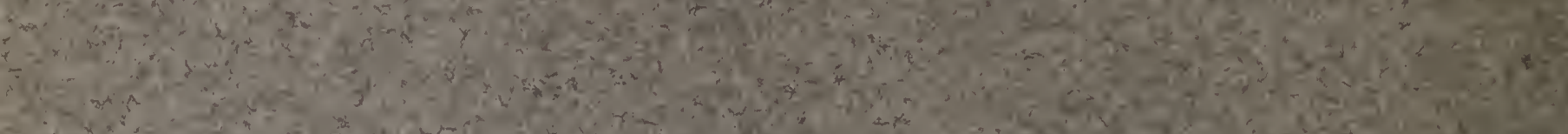

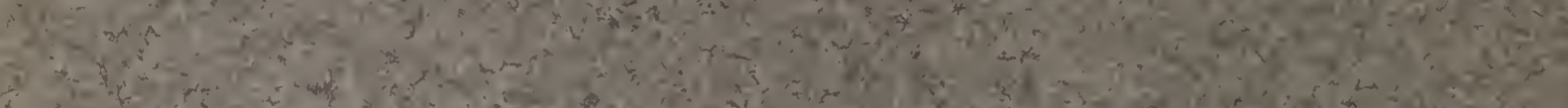

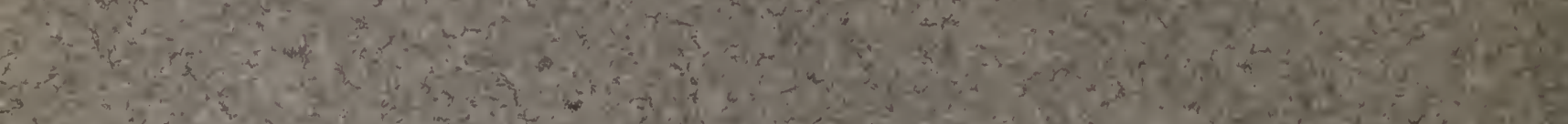

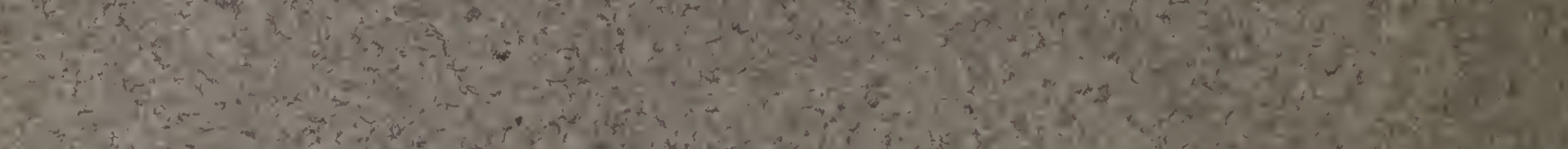
that

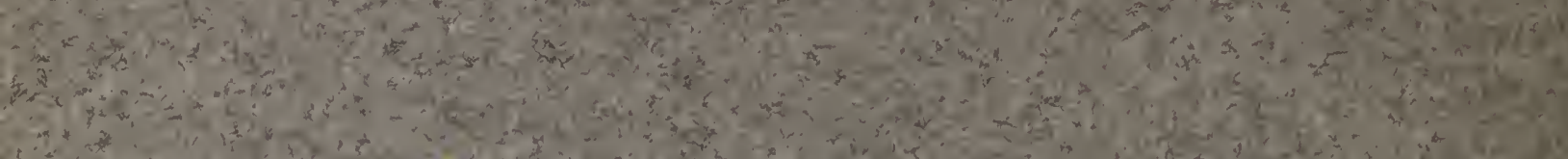

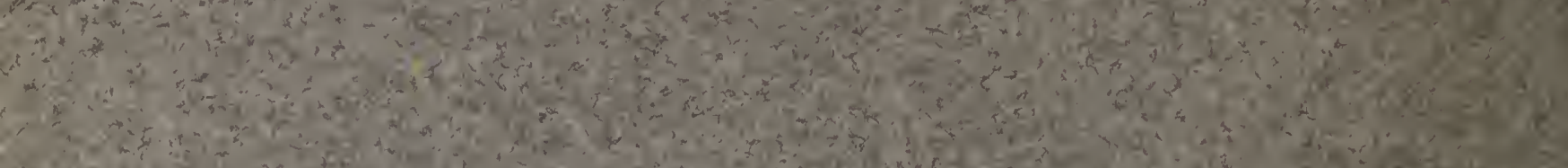

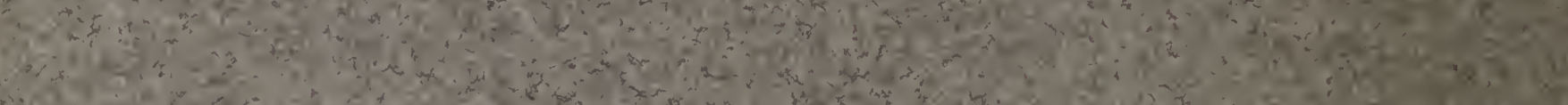

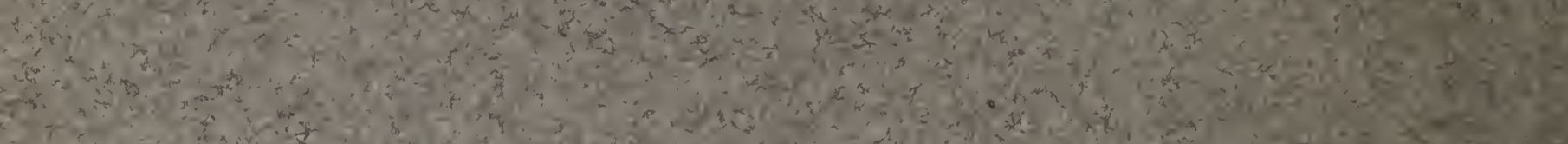

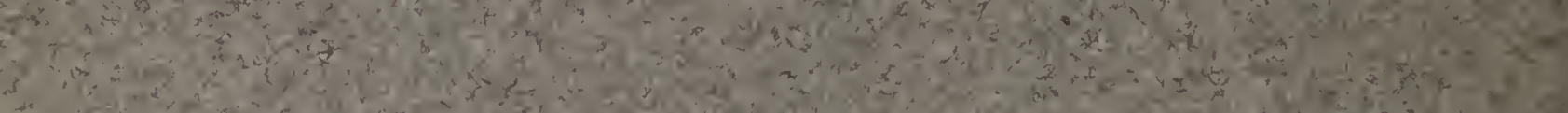

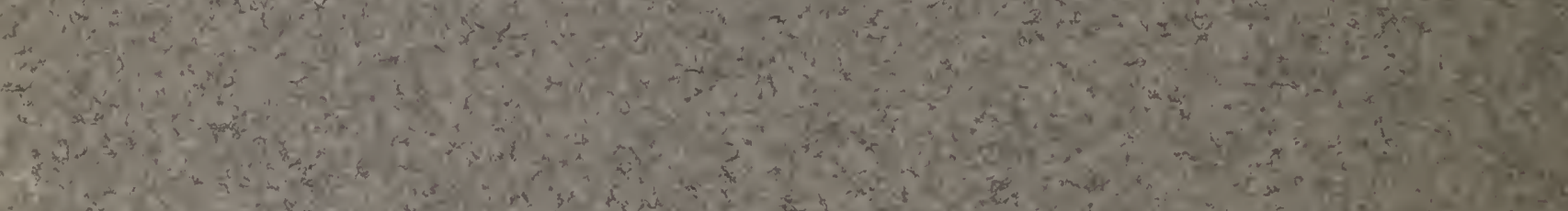

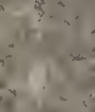
(5)

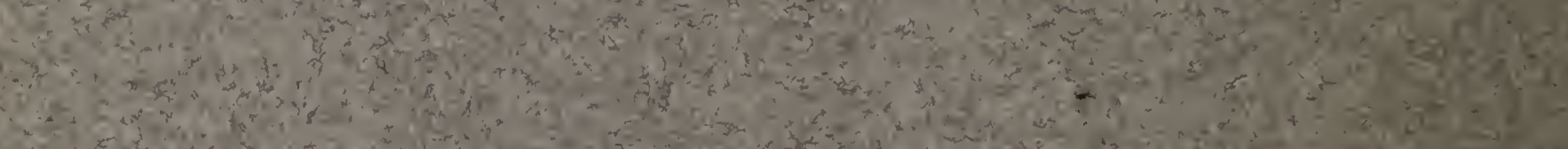

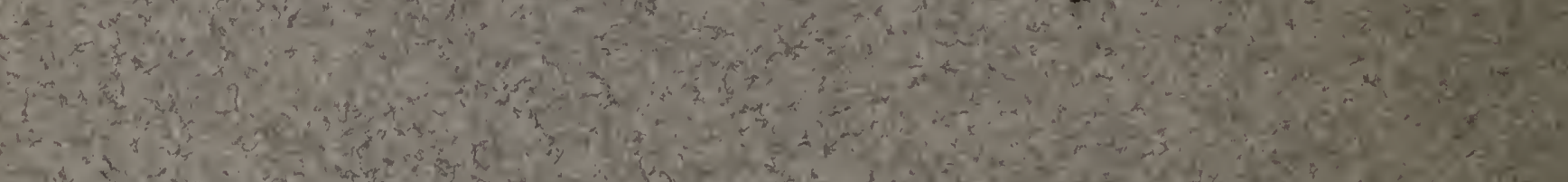

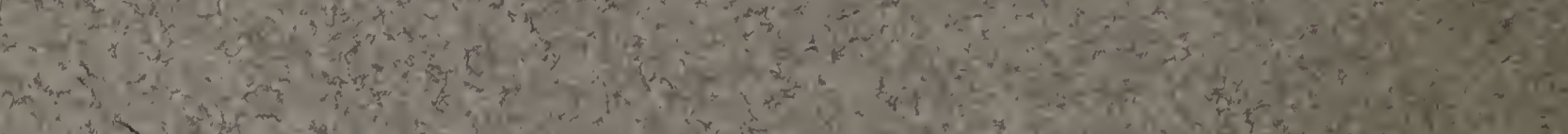

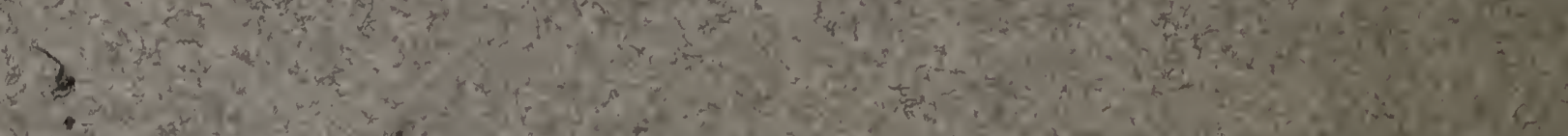

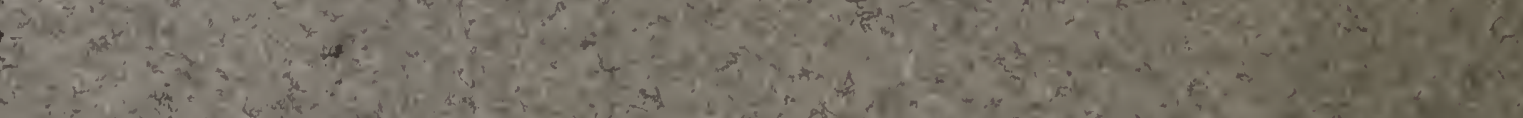

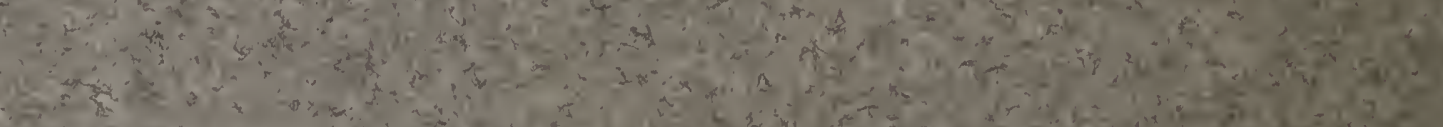

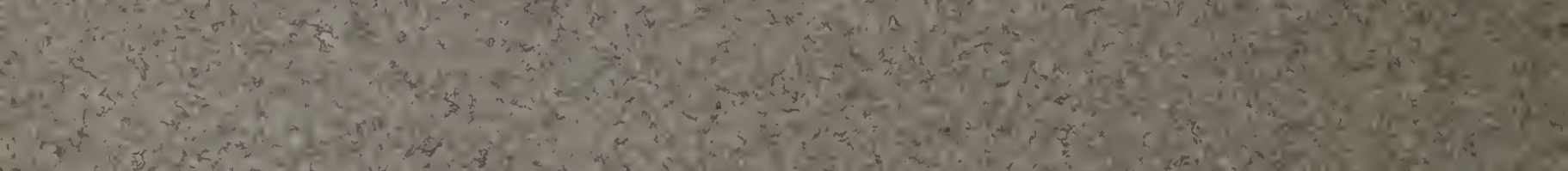

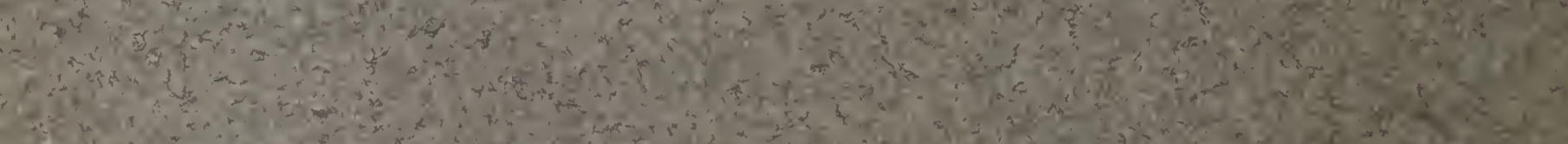

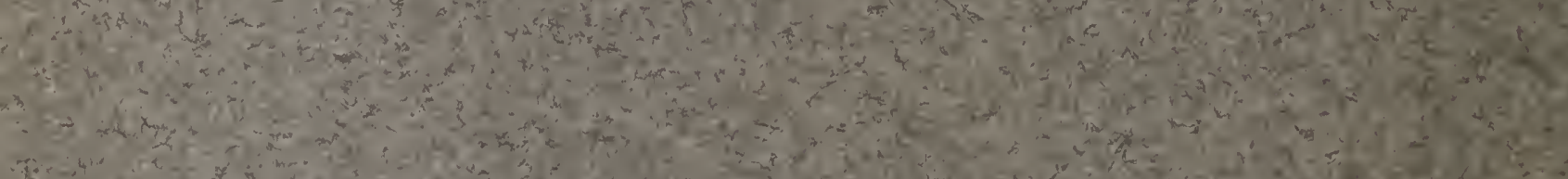

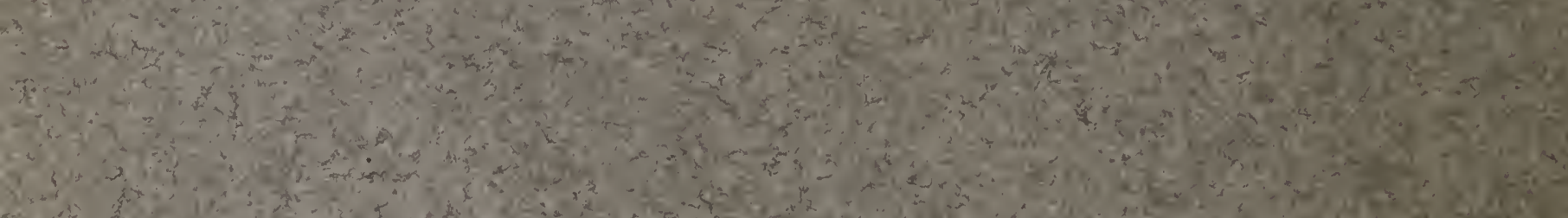
ato

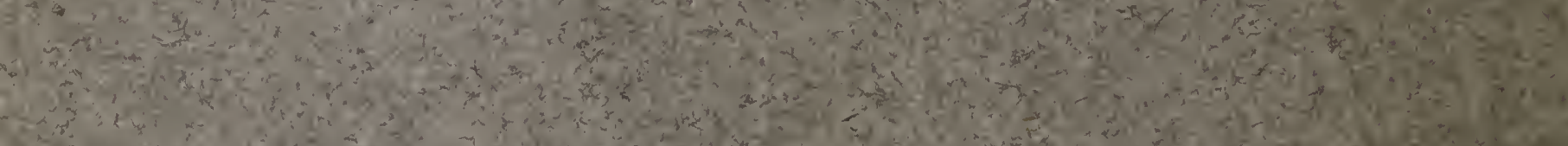

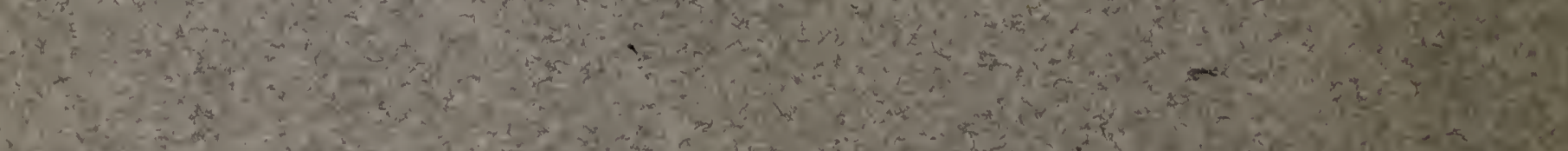

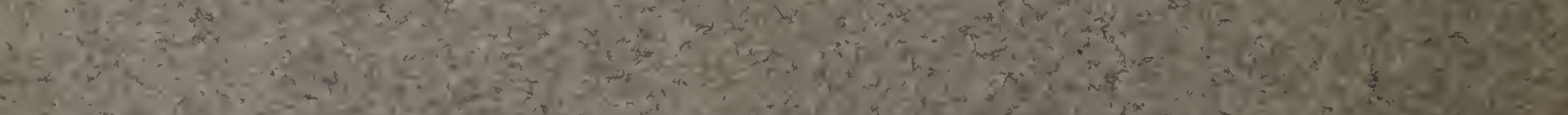


DEPARTMENT OF THE INTERIOR

UNITED STATES GEOLOGICAL SURVEY

GEORGE OTIS SMITH, DIRECTOR

BULLETIN 395

\title{
RADIOACTIVITY OF THE THERMAL WATERS OF YELLOWSTONE NATIONAL PARK
}

\author{
BY \\ HERMAN SCHIUNDT \\ AND \\ RICHARD B. MOORE
}

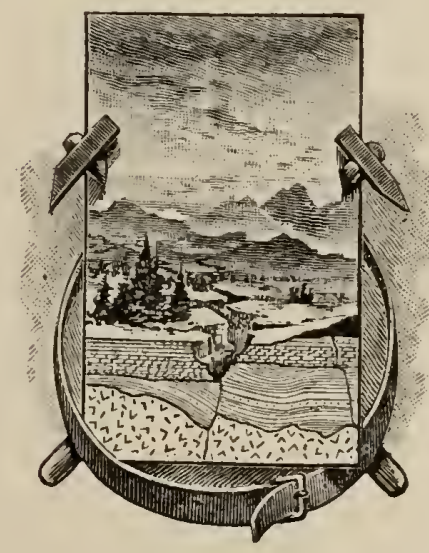

W A S H I N TO $\mathrm{T}$

G O V W N M I N T P I N T NG OF F C E

1909 



\section{CONTENTS.}

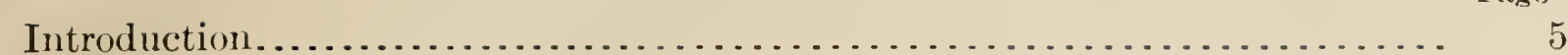

Purpose of the report...................................... 5

Waters in Yellowstone Park................................ 5

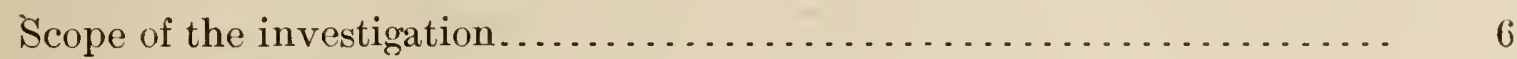

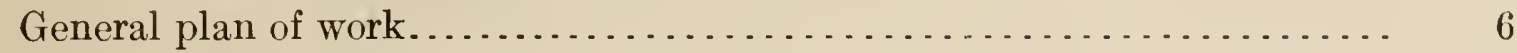

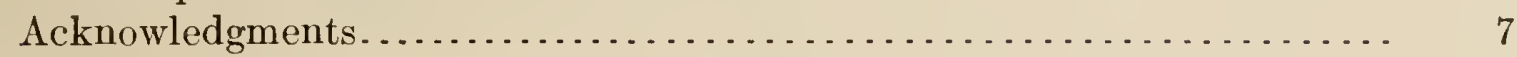

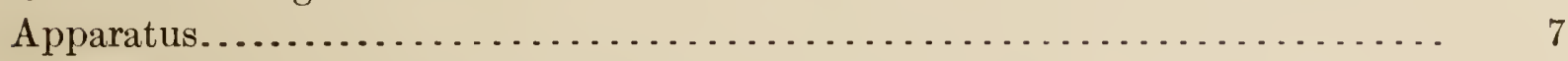

Description of electroscopes................................. 7

Standardizing the electroscopes................................ 9

Electric capacity.............................................. 12

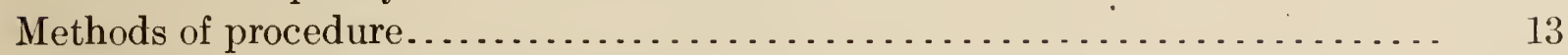

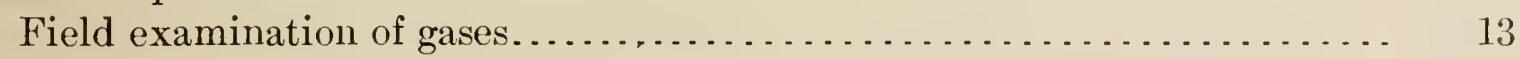

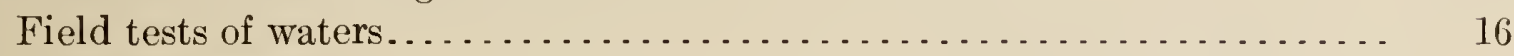

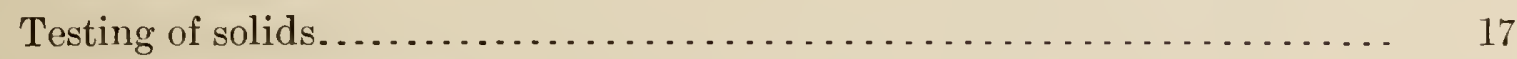

Results of the experiments.................................... 18

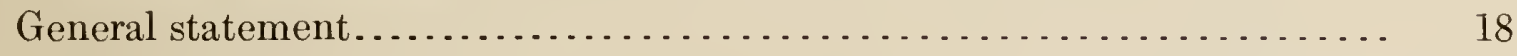

Example showing method....................................... 18

Radioactivity of gases............................................ 20

Radioactivity of waters....................................... 22

Radioactivity of water residues, spring deposits, and rock samples...... $\quad 25$

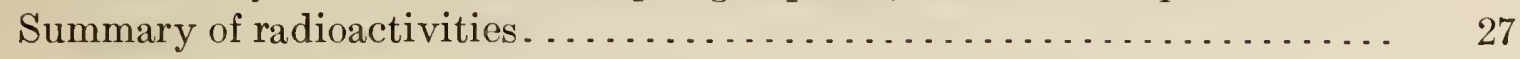

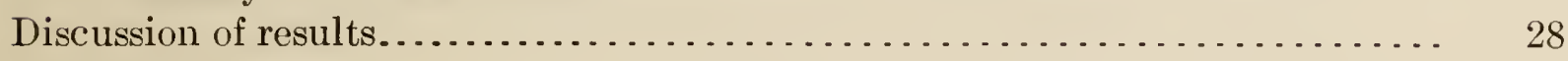

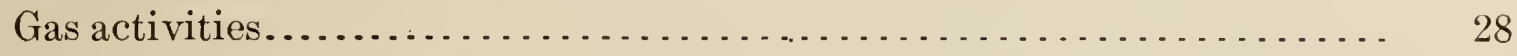

Thorium emanation................................... 28

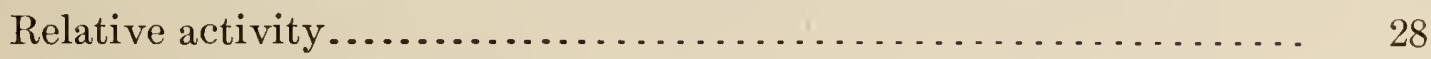

Gases from European springs............................. 29

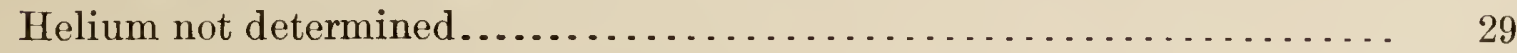

Activity of waters.......................................... $\quad 30$

Inferences from different results.......................... 30

Comparison with European waters........................ 31

Radium content of deposits of rocks ....................... 32

Comparative activities of different rocks .................. 32

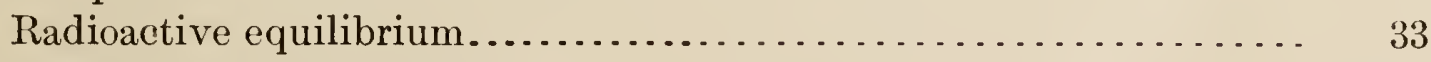

Estimate of age of deposits.............................. 33

Comparative test for uranium by analysis.................. 34

Relation to hydrothermal activity........................... 34 


\section{ILLUSTRATIONS.}

Piate I. Grotto Geyser, Yellowstone National Park

II. Norris Geyser Basin................................. 18

III. A, Old Faithful Geyser, Upper Geyser Basin; $B$, Hot Spring, Norris Geyser Basin, where thorium was first discovered in the United

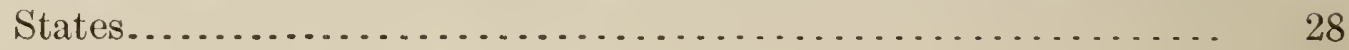

IV. Morning Glory Pool, Upper Geyser Basin.................. . 32

Figure 1. Electroscope...................................... 8

2. Apparatus for separating emanation from uraninite........... 10

3. Apparatus for qualitative tests in the field................. 13

4. Curves showing difference in the radioactivity of gases containing (A) thorium and radium emanation and (B) radium emanation... $\quad 14$

5. Apparatus for collecting gas in the field .................. 15

6. Detail of apparatus for collecting gas in the field........... 15

7. Decay curve of radium emanation................... 16 4 



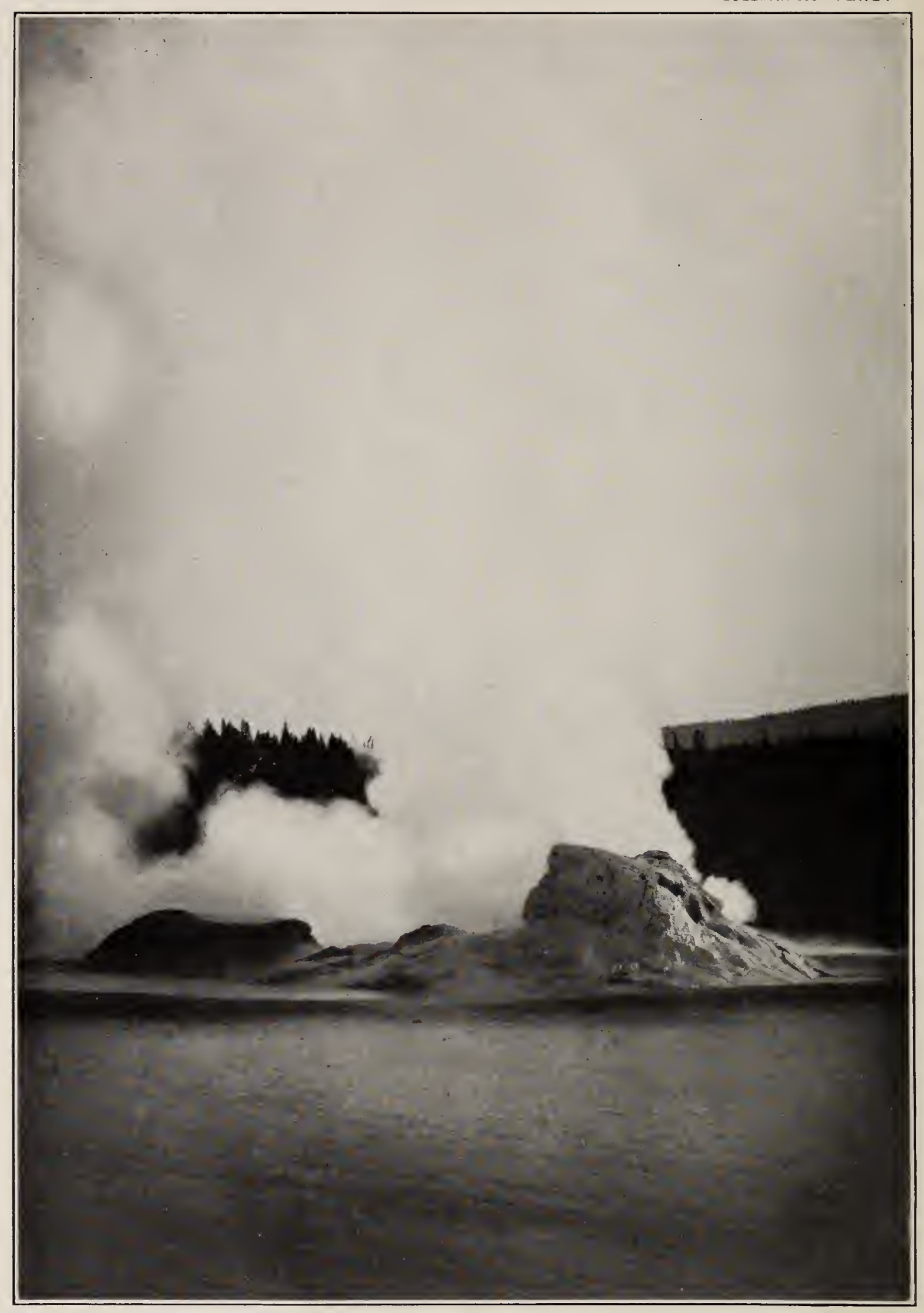

GROTTO GEYSER. 


\title{
RADIOACTIVITY OF THE THERMAL WATERS OF YELLOWSTONE NATIONAL PARK.
}

\author{
By Herman Schlundt and Richard B. Moore.
}

\section{INTRODUCTION.}

\section{PURPOSE OF THE REPORT.}

During the summer of 1906 we conducted a series of field tests for the United States Geological Survey with the object of determining the radioactive properties of the thermal waters of the Yellowstone National Park. In connection with the field work, samples of deposits formed by the springs, some typical rock specimens, and a number of water residues were obtained. In this bulletin the quantitative data of the investigation are presented in a series of tables. An account of the methods of experiment in both field and laboratory precedes the presentation of results, and a discussion follows. We have indicated a possible application of some of the data to a geologic question-the age of some of the spring deposits; but no systematic attempt has been made to relate the facts of radioactivity to the hydrography of the region or to the geology of the park. Since our experiments were conducted chiefly from the chemist's point of view, we have limited our discussion to pointing out the more important characteristics and relations of the data, and comparing them with dáta on radioactivity in other regions of hydrothermal activity.

\section{WATERS IN YELLOWSTONE PARK.}

The thermal waters of the national park are classified by Arnold Hague under three heads, on the basis of incrustations formed by the springs and chemical analyses of some of the waters made by Gooch and Whitfield: ${ }^{~(1) ~ C a l c a r e o u s ~ w a t e r s ~ c a r r y i n g ~ r e l a t i v e l y ~}$ large quantities of calcium carbonate in solution: (2) siliceous acid waters which usually carry free acid in solution and possess an astringent taste; (3) siliceous alkaline waters. In all, about 4,000 hot springs are found in the park and about a hundred geysers.

$a$ Gooch, F. A., and Whitfield, J. E., Analyses of waters of the Yellowstone National Park: Bull. U. S. Geol. Survey No. 47, 1888. 
There is but one important group of calcareous waters in the park, namely, Mammoth Hot Springs, near the northern boundary. In the course of their underground flow these waters pass through Jurassic and Cretaceous limestones and become charged with carbon dioxide and mineral matter, which is deposited as travertine. A series of terraces extend more than a mile up a valley and to a height of 1,300 feet. The springs of this locality differ considerably in temperature, the maximum being $74^{\circ} \mathrm{C}$, about $18^{\circ}$ under the boiling temperature of water at this altitude.

Acid waters occur in the following localities among those we visited: Norris basin, Shoshone basin, Heart Lake basin, Crater Hills, Tower Falls, Mount Washburn, Mud Volcanoes near Yellowstone River, and Grand Canyon of the Yellowstone.

Alkaline waters predominate in the regions of geyser activity. These waters deposit an incrustation of amorphous silica. Springs of this class were tested at Upper and Lower Geyser basins, Excelsior basin, Shoshone basin, Heart Lake basin, and West Thumb of Yellowstone Lake.

\section{SCOPE OF THE INVESTIGATION.}

The field tests extended over a period of two months, during which all the principal basins of thernal activity were visited. The spring waters examined embrace the different types found in the park and include water from a number of cold springs. The aim was to test one or more of each type at each basin visited. Wherever gases were evolved from a spring, these also were tested for their radioactive properties. About eighty quantitative tests were made of waters and forty of gases, besides nearly ninety tests of gases largely of a qualitative nature. In the laboratory some fifty solids, consisting of spring deposits, water residues, and rock samples, were examined quantitatively for the radium content.

\section{GENERAL PLAN OF WORK.}

The determinations for radioactivity were all made by the electrical method. Several electroscopes of the C. T. R. Wilson type, as modified in some details by Doctor Boltwood and ourselves for this kind of work, were employed in both field and laboratory tests. The procedure in the field was generally as follows: A qualitative test for radium and thorium emanation was first conducted on the escaping gas from the spring. This was followed by a quantitative determination of the radium emanation present in the gas. Meanwhile a sample of the spring deposit was collected and a sample of water taken. Incidentally the temperature of the water was taken and its reaction toward litmus paper tested. At the field laboratory the quantity of radium emanation in the sample of water collected 
was determined, after which the water was evaporated to dryness. The residue thus obtained and the sample of deposit made by the spring were subsequently examined for their radium content in a chemical laboratory.

\section{ACKNOWLEDGMENTS.}

The United States Geological Survey defrayed the greater portion of the expense connected with the field tests of this investigation. The Northern Pacific Railway furnished transportation between St. Paul and Gardiner, Mont. The University of Missouri and Butler College loaned most of the scientific apparatus used in the field tests, and the determinations of radium present in the spring deposits and rock samples were conducted in the chenical laboratories of these institutions. The field work came under the direction of $\mathrm{C}$. W. Hayes and Arnold Hague, of the United States Geological Survey. Doctor Hague also placed at our disposal several specimens of typical rocks, which were used in determining the radium content of rocks. Maj. John Pitcher, U. S. Army, extended numerous facilities that materially aided in the field experiments. Capt. William H. Forsythe, U. S. Army, collected several samples of travertine for us at Mammoth Hot Springs. The noncommissioned officers stationed at the military posts throughout the park assisted in various ways.

\section{APPARATUS.}

\section{DESCRIPTION OF ELECTROSCOPES.}

Three air-tight electroscopes of the C. T. R. Wilson type were employed in the field and laboratory tests. Two of these we had used in a previous investigation on the radioactivity of waters. ${ }^{a}$ These instruments were constructed in the main according to the specifications given by Boltwood. ${ }^{b}$ Figure 1 shows one of the electroscopes but does not show the reading microscope for observing the fall of the leaf. The instrument consists of a rectangular brass frame 15 by 10 by 6 centimeters, fitted on the front and back with pieces of plate glass. On the top, the frame carries a short piece of wide glass tubing $(\mathrm{T})$ surmounted by a threaded brass ring $(\mathrm{R})$, into which a removable brass cap (C) screws. A short piece of glass tubing passes through a hole in the cap and a brass rod $(r)$ is cemented in the glass tube by means of sulphur or wax. The lower end of the brass rod extends into a rod of sulphur, which serves as the insulating material to support the leaf system. The plate $(p)$ to which the leaf is fastened is embedded for a short distance in the other end of the sulphur rod. A special feature of the electroscope is the device 
for charging it. ${ }^{a}$ A piece of soft iron wire $(w)$ is suspended from a hook on the brass rod $(r)$ which projects out through the screw cap. The wire extends just below the sulphur insulator and terminates in a right-angle bend. In its normal position the wire does not touch the plate carrying the leaf, but by bringing a magnet near the wire,

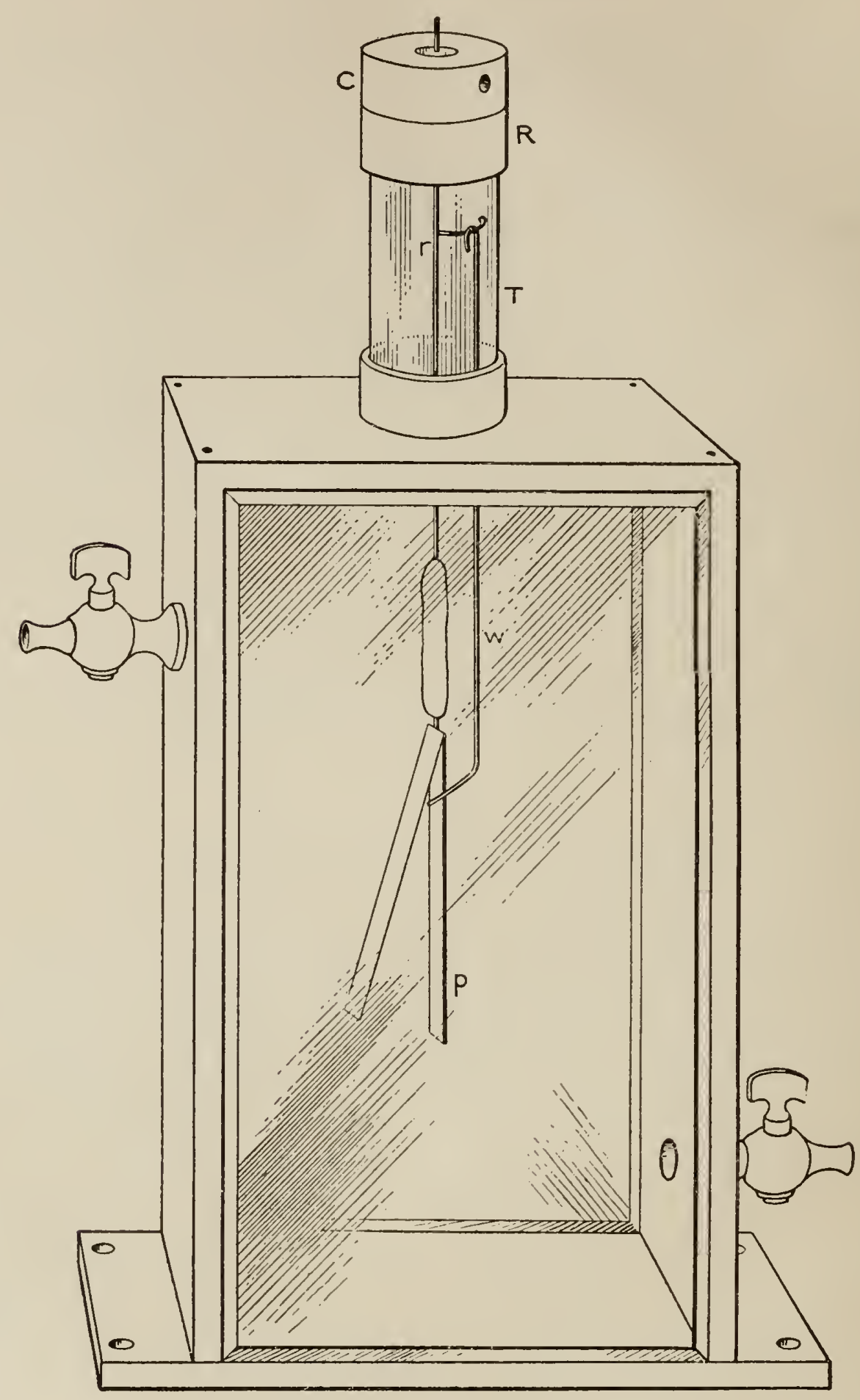

Figure 1.-Electroscope.

it can be deflected so as to make metallic contact between the rod ( $r$ ) and the plate $(p)$. All of the brass joints are soldered and the other joints are made air-tight by means of hot wax, except that between the brass ring and cap, where a rubber washer excludes the air. The electroscope is provided with two good brass stopcocks.

a The same device was used by Strutt, Phil. Mag., 6th ser., vol. 5, 1903, p. 680; and by Boltwood, loc. cit. 
Alumirum leaf was used in the instruments. It was readily and firmly fastened to the carrying blade by moistening the upper portion of the blade and then pressing it firmly against the leaf. The sulphur rod and the aluminum leaf successfully withstood the transportation by rail and in the field. In two of the electroscopesthe original leaf served throughout the entire series of field experiments. The volume of the electroscopes was, respectively, 490, 590, and 600 cubic centimeters. A rod of vulcanite about 20 centimeters long was used for charging. After metallic connection between the leaf system and the projecting rod had been made, the charged vulcanite was touched to the brass rod, and by gentle rubbing, the desired potential on the leaf system was produced. After withdrawing the vulcanite the rod and cap were earthed for an instant.

Each electroscope was fastened securely to a wooden base. The fall of the leaf was observed by means of a microscope firmly supported by a brass holder which was likewise screwed to the wooden base. The glass scale in the eyepiece was divided into ten divisions and each of these was again divided into tenths. The diameter of the field corresponding to the hundred small divisions of the scale was approximately 5.2 millimeters for each of the microscopes. The rate of fall of the leaf was generally obtained by noting the time required for the leaf to fall 60 small divisions between the same two points of the scale. The time interval was measured by means of a stop watch recording fifths of a second. To secure uniform and ready adjustment of the instruments for the field tests a circular level was attached to the base. Suitable carrying cases were constructed for the electroscopes to facilitate their safe transportation in conducting the outdoor experiments.

\section{STANDARDIZING THE ELECTROSCOPES.}

To make quantitative activity measurements by means of electroscopes, each instrument must be standardized. The method of standardizing employed was the one first proposed by Boltwood, ${ }^{a}$ which we had adopted in our earlier electroscopic determinations of radium emanation in waters. ${ }^{b}$ Strutt has followed a similar procedure in his extensive investigations on the radium content of rocks and spring deposits. ${ }^{c}$ The method is based upon the well-established fact that the radium present in natural uranium minerals stands in constant ratio to the uranium. Rutherford and Boltwood ${ }^{d}$ have recently redetermined this ratio and found that one gram uranium is in radioactive equilibrium with $3.8 \times 10^{-7}$ grams radium. If then the emanation from a small weighed quantity of a uranium mineral, 
whose percentage of uranium is known from a chemical analysis, be introduced into the electroscope, and the rate of fall of the leaf noted, the data are at hand from which a constant for the electroscope may be calculated that shall express the uranium (or radium) required to produced a fall of the leaf one division in unit time.

The operation of standardizing was carried out as follows: The apparatus used for separating and collecting the emanation is shown

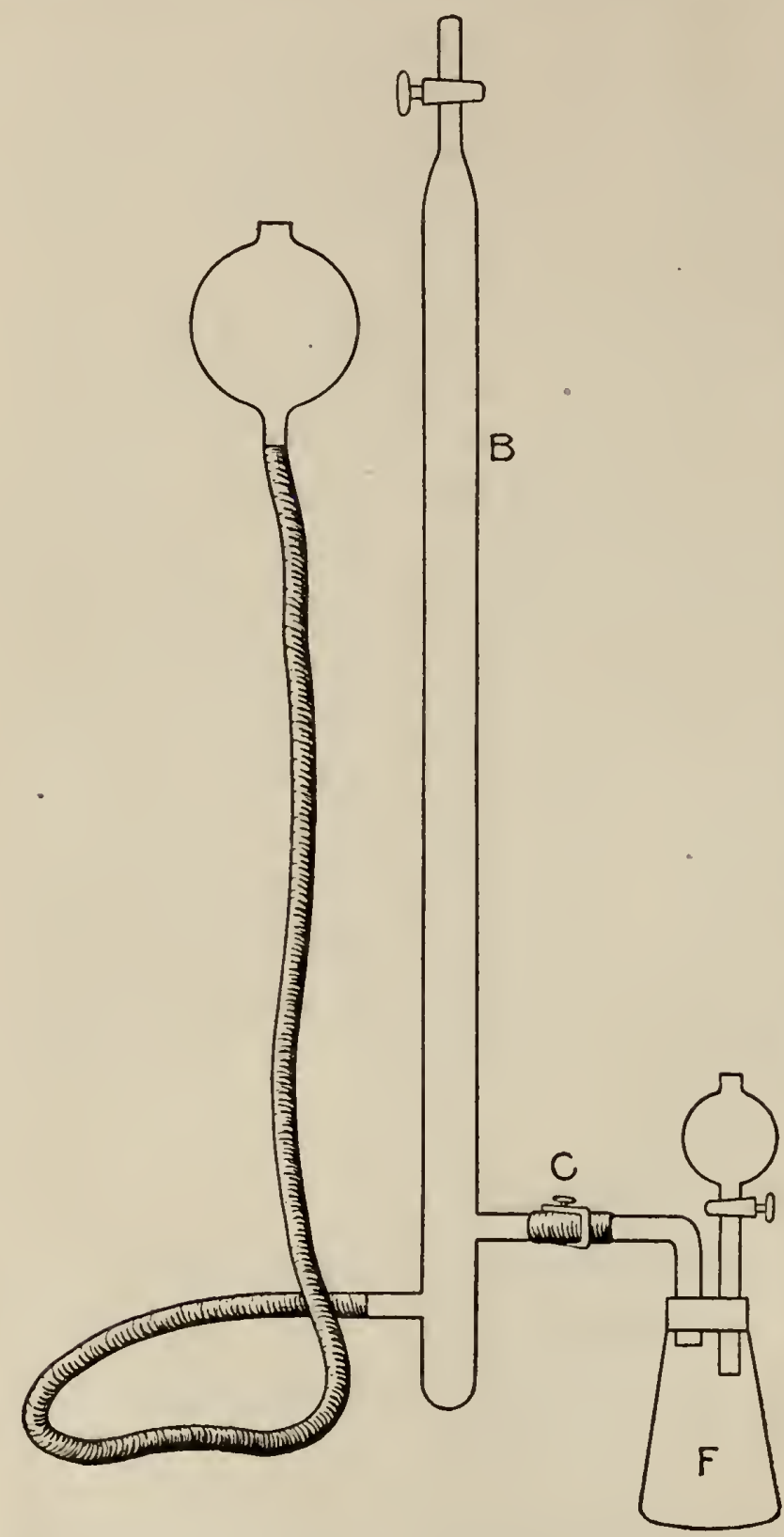

FIGURE 2.-Apparatus for separating emanation from uraninite.

in figure 2. A small quantity of a standard sample of powdered uraninite containing 68.9 per cent uranium was weighed out and put in the flask (F), of about 50 cubic centimeters capacity. Generally 15.7 milligrams of uraninite was used, as the emanation separated from this quantity of the mineral upon solution represents the total emanation associated with 10 milligrams uranium. A rubber stopper fitted with a small dropping funnel and a short delivery tube was then inserted in the flask and connections were made with the gas burette (B), which had previously been filled with freshly boiled distilled water, to which a few cubic centimeters of sodium hydroxide had been added. A few cubic centimeters of diluted nitric acid was then poured into the drop funnel; the leveling reservoir of the gas burette was lowered below the level of the acid in the funnel; and then by opening the pinchcock $(c)$ and the stopcock of the funnel most of the acid was allowed to flow into the flask. The stopcock was then closed, the leveling reservoir replaced, and the flask gently heated until the uraninite had dissolved. When any gas collected in the stem of the funnel during this operation it was displaced by water introduced through the funnel. By withdrawing the flame for a moment sufficient water was allowed to flow into the flask to continue the boiling for ten minutes. The gas collected in the burette, after standing for ten 
minutes, was then introduced into the electroscope, which had previously been partly exhausted, to be standardized. After three hours, the time in which the activity attains a maximum, the rate of leak was determined.

The standardizing record of one of the electroscopes, which is designated in our journal as No. 1, is given below in Table 1. The quantity of uraninite used in each experiment was 15.7 milligrams. Determinations numbered 3 and 4 were conducted in Yellowstone Park in the field laboratory, and the others were made in the chemical laboratory of the University of Missouri. The samples of uraninite used for standardizing in the park were carefully weighed out and sealed in small glass tubes before we started for the field work. The first column in the table gives the number of the experiment; the second, the date on which it was conducted; the third, the number of scale divisions the leaf fell per minute at the time of maximum activity - three to three and one-half hours after the introduction of the gas. The normal air leak of the electroscope, 0.15 division per minute, has been deducted from the readings. The last column gives the constants computed for the electroscope. These values represent the quantity of uranium that would cause a fall of the leaf of one scale division per minute, if all of the emanation produced remained in the sample. In this particular sample of uraninite, 7.6 per cent of the emanation is continuously lost at room temperatures. The quantity of uraninite used in the experiments, however, 15.7 milligrams, contains the maximum quantity of emanation that would be found associated with 10 milligrams of uranium. The sample taken contains 10.8 milligrams of uranium. Hence the quantity of uranium responsible for a leak of one division per minute if all the emanation produced were retained is obtained by dividing 10 milligrams by the observed leak per minute.

TABLE 1.-Standardizing record of electroscope No. 1.

\begin{tabular}{|c|c|c|c|}
\hline Number. & Date. & $\begin{array}{l}\text { Observed } \\
\text { leak (divi- } \\
\text { sions per. } \\
\text { minute). }\end{array}$ & $\begin{array}{l}\text { Uranium } \\
\text { per divi- } \\
\text { sion per } \\
\text { minute } \\
\text { (grams } \\
\left.\times 10^{-4}\right)\end{array}$ \\
\hline 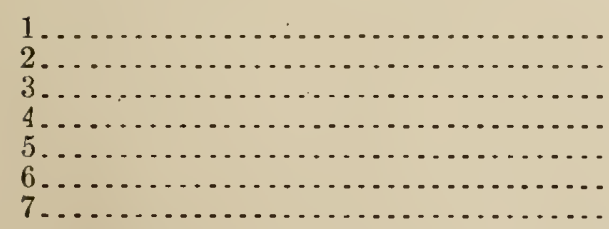 & $\begin{array}{l}\text { June } 28,1905 \\
\text { Aug. } 15,1905 \\
\text { July } 19,1906 \\
\text { Aug. } 24,1906 \\
\text { Nov. } 14,1906 \\
\text { Mar. } 8,1907 \\
\text { May } 22,1907\end{array}$ & $\begin{array}{l}44.1 \\
45.0 \\
35.5 \\
37.0 \\
48.0 \\
42.8 \\
45.7\end{array}$ & $\begin{array}{l}2.27 \\
2.22 \\
2.88 \\
2.70 \\
2.07 \\
2.35 \\
2.18\end{array}$ \\
\hline
\end{tabular}

The table shows that the constants obtained in the park are approximately 25 per cent higher than the average of the values obtained at Columbia, Mo. The lower density of the air at the higher altitude is 
an important cause of this difference. The value $2.8 \times 10^{-4}$ was used for this electroscope in converting scale readings taken in the field to the uranium standard. The radium constant of the electroscope during the field tests was the product of $2.8 \times 10^{-4}$ and $3.8 \times 10^{-7}$, or $10.64 \times 10^{-11}$.

In the field the constant for electroscope No. 2 was found to be $7.7 \times 10^{-4}$ grams uranium and for electroscope No. 3 the value was $1.52 \times 10^{-4}$ grams uranium for a leak of one scale division per minute.

\section{ELECTRIC CAPACITY.}

Inasmuch as some investigators, chiefly those on the continent of Europe, have expressed their quantitative results for the radioactivity of water and gas samples in electrostatic units, we have standardized two of our electroscopes in C. G. S. units." We are thereby enabled to express our values in absolute units and to compare the activities obtained with those given for some of the wellknown thermal waters of foreign countries.

In expressing the radioactivity of waters, the standards proposed by Curie and Laborde ${ }^{a}$ and by Mache ${ }^{b}$ have been generally adopted. The activity is the value obtained in electrostatic units for the saturation current produced by the radium emanation present per liter of water. For gases the saturation current produced by a liter of the gas is given as its radioactive value. Mache, in expressing the value of activities, deducted from the observed values the current due to the disintegration products of the radium emanation. The values given by Curie and Laborde represent approximately the total maximum activity, which includes the activity of the disintegration products of the emanation.

To express the saturation current in electrostatic units two quantities must be determined-(1) the rate of fall of the leaf in volts per unit of time and (2) the electric capacity of the leaf system. In making our electroscopic readings we found the number of divisions the leaf fell per minute. To convert these readings into volts it is only necessary to calibrate the scale in the eyepiece of the reading microscope between the two points for which readings were generally made. This operation was conducted as follows: The glass plate on the back of the electroscope was replaced by one of cardboard, which was provided with an opening about 1.5 centimeters square, opposite the point where the leaf is attached to the carrying blade. The leaf system was then connected through the opening in the cardboard to one pole of a set of small storage batteries and the case of the electroscope to the other pole. The positions of the leaf corresponding to several voltages between 300 and 400 were then noted. In this way it was 
found that one small division of the scale of electroscope No. 1 represented 1.24 volts, and for electroscope No. 2 one division represented 2.80 volts. The electric capacity of the electroscopes was determined by means of a Harms standard condenser whose capacity was 42.5 centimeters. The procedure given by Harms ${ }^{a}$ was carefully followed. Connections with the leaf system were again made through the opening in the cardboard. The capacities of the instruments were small; that of electroscope No. 1 was found to be 2.81 centimeters and that of No. 2, 3.51 centimeters. The leaf system of electroscope No. 1 had the following dimensions: The aluminum leaf was 1.0 centimeter wide and 5.4 centimeters long, and it was fastened to a blade 0.9 centimeter wide and 6.2 centimeters long.

\section{METHODS OF PROCEDURE.}

FIELD EXAMINATION OF GASES.

From many of the springs in the park gases escape with the issuing water. In some instances the evolution of gas from the hot water is so copious as to give the appearance of boiling. It is also not uncommon to see gases bubbling up in considerable quantity at certain points in the pools of hot water that dot the sinter plain in most of the different basins of thermal activity. Systematic tests were conducted with the escaping gases throughout the series of field experiments. The gas activity was generally the first determination made. It was conducted at the spring and consisted of two parts: (1) A qualitative test for the detection of thorium emanation as well as radium emanation; (2) a quantitative determination of the radium emanation present in the gas.

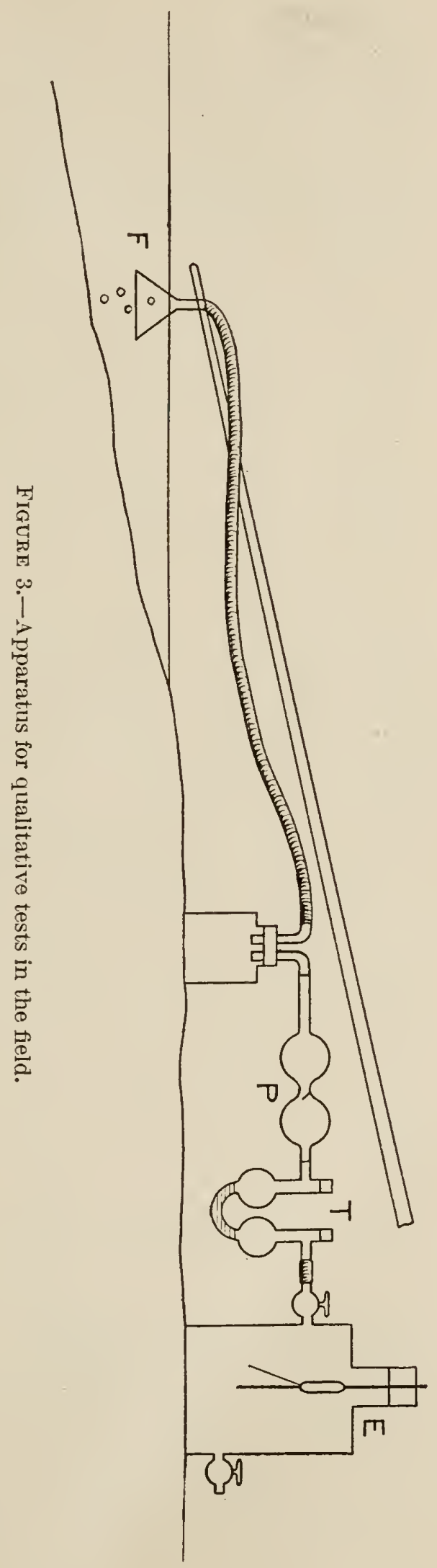

The principal parts of the apparatus used in the qualitative test are shown in figure 3: A glass collecting funnel (F) 12 centimeters in diam- 
eter, a rubber hand bellows $(\mathrm{P})$, a drying tube (T) containing strong sulphuric acid, and one of the electroscopes (E) were connected in series by rubber tubing. By operating the hand bellows the water gas collecting in the funnel was gradually made to displace most of the original air in the electroscope. One to five minutes was generally required for this operation, the time depending upon the rate at which the gas collected in the funnel. When 1 to 2 liters of gas had been passed along the circuit, the pumping was stopped and the cocks of the electroscope closed. The leaf was then quickly charged and readings taken on its rate of fall by means of a stop watch and

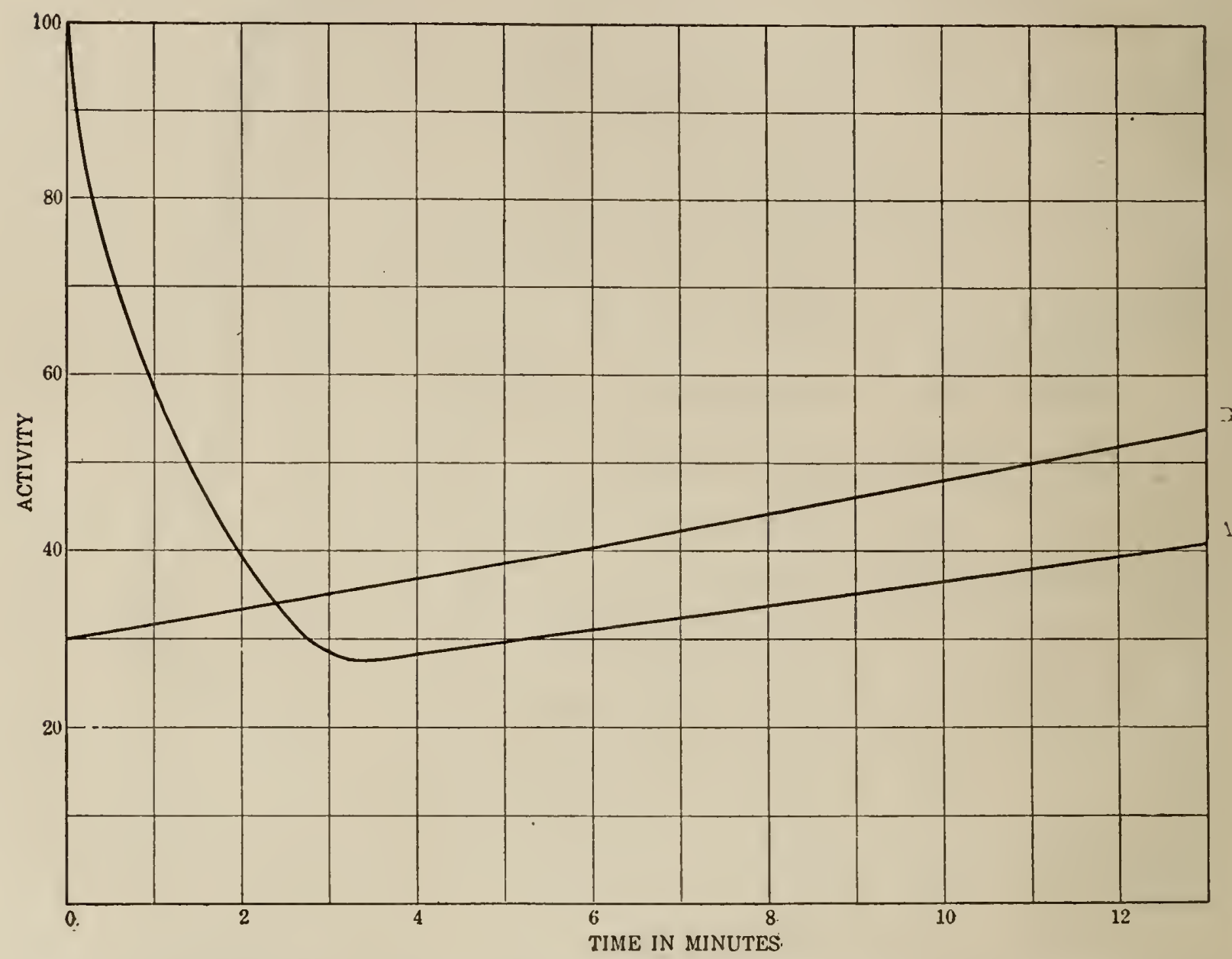

FIGURE 4.-Curves showing difference in the radioactivity of gases containing (A) thorium and radium emanation and (B) radium emanation.

the reading microscope. By taking readings at suitable intervals for five to ten minutes the presence of thorium as well as radium emanation could be detected. Sometimes the leaf was charged before the transfer of gas through the electroscope was interrupted, so that readings could be taken at the instant the leaf appeared in the field of the microscope. By the latter procedure the relative activities of the thorium and radium emanation in the electroscope may be more readily obtained.

In figure 4 the points for curve $A$ represent a series of readings obtained with a gas containing both thorium and radium emanation, and 
curve B represents the data for a gas containing only radium emanation. The activity is given in an arbitrary scale for the time in minutes. In the gas containing both emanations the activity drops very rapidly at first, falling to approximately half value in a minute-the characteristic rate of decay of thorium emanation. The activity remaining after five minutes mainly represents that of the radium emanation, showing its characteristic initial rise, as in curve B. After readings had been taken for ten minutes the gas in the electroscope was blown out with the hand bellows to avoid the accumulation of the disintegration products of the emanation. After half an hour theinstrument was generally ready for another test.

If the escaping gas was

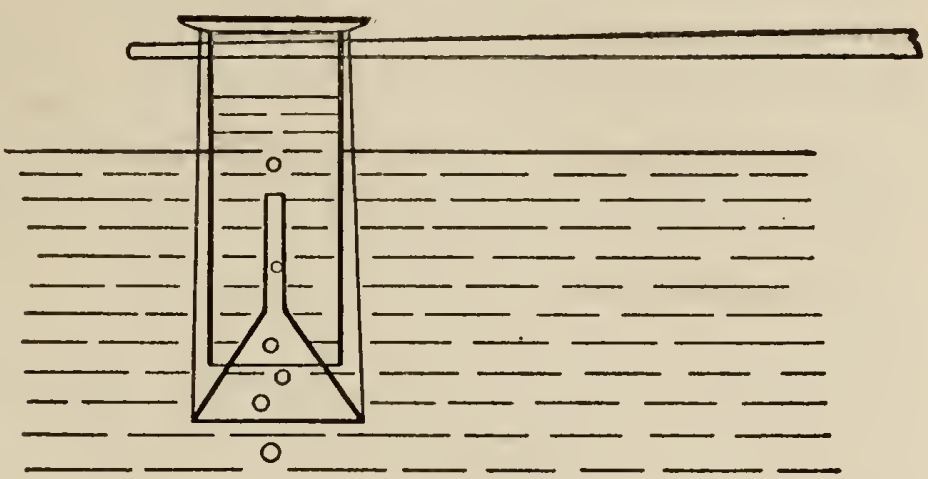

FIGURE 5.-A pparatus for collecting gas in the field. found to be active, a known volume was collected over water and this was introduced into an electroscope, which had previously been partially exhausted, for a quantitative determination of the radium emanation. The device generally employed for collecting the gas is shown in figure 5. A collecting funnel and a graduated cylinder attached to a pole were filled with water and then inverted over

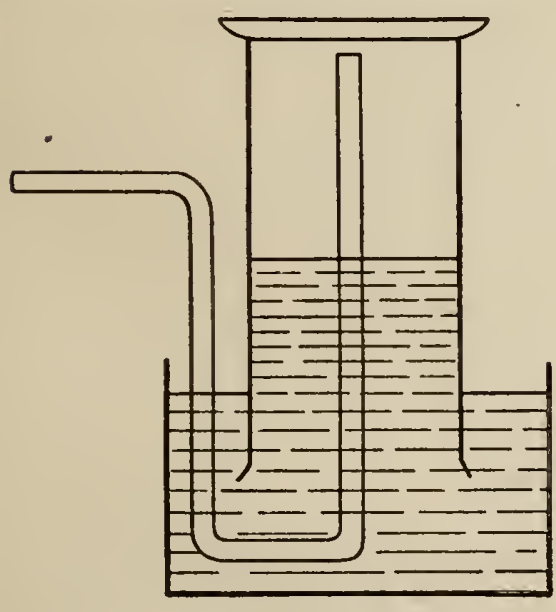

FIGURE 6.-Detail of apparatus for collecting gas in the field. the escaping gas. When 50 to 100 cubic centimeters of gas had collected in the cylinder, it was brought within arm's reach, the funnel removed under water, the cylinder transferred to a small pneumatic trough, and the whole removed from the pool to cool. To hasten the cooling, the trough was oftentimes placed in a larger vessel of cold water. After ten minutes the temperature of the water was taken and the volume of the gas read. In the meantime a rubber tube supplied with a pinchcock was introduced up the cylinder, as shown in figure 6 . The gas was then transferred to the partially exhausted electroscope with the drying train in circuit. The water gas remaining in the train and tubing was swept into the electroscope by admitting outside air until atmospheric pressure was restored. The rate of fall of the leaf was then taken at intervals during several hours following. The maximum activity, reached about three hours after the introduction of the gas, was made the basis of calculations 
in these measurements. Figure 7 represents the results obtained in one of these determinations. After four hours (point B on the curve) the gas was blown out. The rapid rate of decay of the induced activity, as well as the initial rise, are characteristic of radium emanation.

\section{FIELD TESTS OF WATERS.}

In almost all the tests the determination of the activity of the water samples consisted in a quantitative measurement of the radium emanation in a fresh sample of water. The emanation dissolved in a known volume of water was separated by boiling in a form of apparatus which had been used in earlier investigations on the radioactivity of

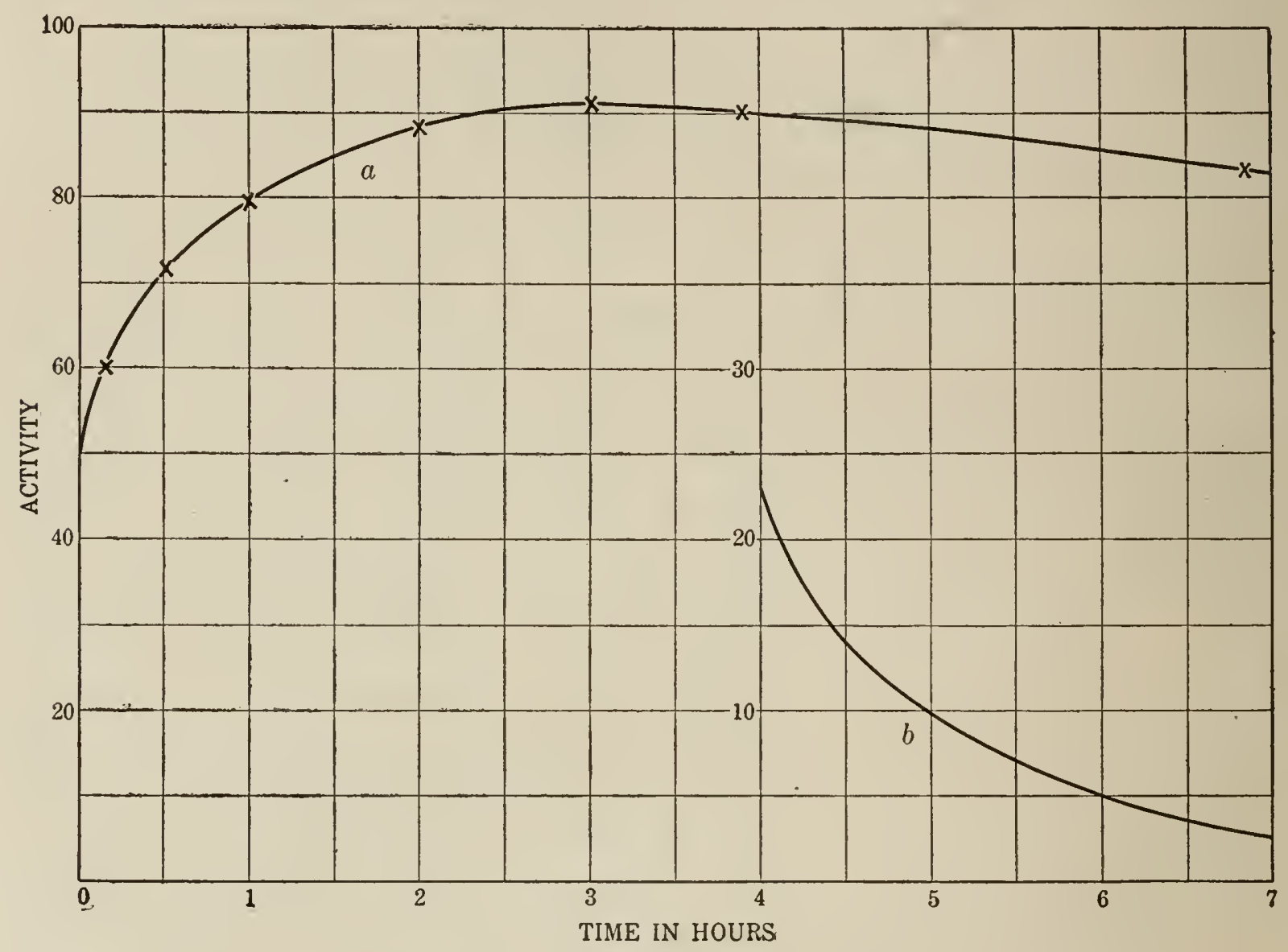

FIGURE 7.-Decay curve of radium emanation.

waters. The apparatus is figured and fully described in the Journal of Physical Chemistry, volume 9, pp. 324-326. Several parts of the apparatus were modified to adapt it to field conditions. Metal vessels were substituted for the glass ones formerly used as leveling reservoirs. The gas burette for measuring the volumes of the separated gases was rarely used. The heating was done with a small wood fire. The boilers used were provided with bails and also served as collecting vessels. A small quantity of caustic soda was generally added to the water sample before boiling to fix the carbon dioxide carried by the waters.

About ten minutes after boiling had ceased the separated gas was drawn into one of the standardized electroscopes, which had pre- 
viously been partially exhausted by means of a hand suction pump. The activity was then ascertained in the usual way by noting the rate of fall of the charged leaf at intervals of fifteen to thirty minutes for several hours. The maximum leak, obtained three and one-half hours after the introduction of the gas, was made the basis for calculating the activity of the water sample.

The presence of radium emanation in a natural water does not necessarily indicate the presence of dissolved radium salts. Being a gas, the emanation found in a water sample may simply have diffused into it in the course of its underground flow. Such a water, however, has only temporary activity, for the emanation when separated from its parent radium decays rapidly, falling to half value in about four days, one-fourth value in eight days, and so on, until at the end of a month the activity has practically disappeared. If radium salts are present the water sample will still be radioactive after standing in a sealed vessel for a month and the residue after evaporation will also be radioactive. The presence of radium salts may be established by either of two methods-(1) by an examination of the residue obtained by evaporation, or (2) by storing the sample from which the emanation has been expelled by boiling, and at the end of a week or two again determining the emanation that has accumulated. As our facilities for storing waters were limited we evaporated the samples and reserved the residues for examination in the laboratory after our return from the park. The water was evaporated on a camp stove in iron bowls of about 2 liters capacity. The greater portion of the residue was removed with a spatula and the firmly adhering portion was removed by vigorous scouring with emery cloth, a fresh piece of cloth being used for each residue.

TESTING OF SOLIDS.

In determining the radium content of the spring deposits, water residues, and rock samples the method devised by Strutt ${ }^{a}$ in his investigations on the distribution of radium in the crust of the earth was followed in the main.

The calcareous deposits were dissolved in hydrochloric acid and the solution stored for several weeks in tightly corked flasks. The weights of material used in these determinations are given in the tabulated statement of results which appears further on. The slight quantities of insoluble residue were not removed, but were stored with the solutions. After the requisite period of storage the accumulated emanation was boiled off in an apparatus similar to the one used in the tests with water samples, except that the flask in which the solution was stored served as the boiler. The quantity of ema- 
nation was then determined, as it was for water and gas samples, by means of a standardized electroscope. With the siliceous deposits and the rock samples the determination of radium in small quantities involves more labor. The sample must first be ground to go through a 100-mesh sieve. Then it is fused with a mixture of alkali carbonates, the mass extracted with water, and the soluble portion stored in a tightly corked flask. The residue after it is dissolved in hydrochloric acid is stored in another flask. The activity of the two solutions is determined at the end of three or four weeks, as before described in connection with the water tests. From the data thus obtained the quantity of radium per gram of substance is readily calculated.

\section{RESULTS OF THE EXPERIMENTS.}

GENERAI, STATEMENT.

The experimental results of this investigation are presented in five tables, showing the radioactivity of gases, waters, water residues, spring deposits, and rock samples. Finally, the results for the activity of gases, waters, and deposits are summarized for better comparison in an additional table.

\section{EXAMPLE SHOWING METHOD.}

The data obtained in the test of White Sulphur Spring at the Lower Geyser basin are summarized here to illustrate the procedure followed and to show the method of calculation of the values given for radioactivity in the tables. The test was conducted August 1, 1906. The temperature of the water in the pool at the point where samples were collected was $59^{\circ} \mathrm{C}$, and the water was slightly alkaline to litmus paper. The gas escaping from two orifices under the water at the south end of the pool were first tested qualitatively for thorium and radium emanation by the use of the apparatus shown in figure 3 . As the gas issued relatively slowly, ten minutes was consumed in passing the accumulating gases along the circuit through electroscope No. 1. About 1,100 cubic centimeters of gas was transmitted, as measured by 15 squeezes of the hand bellows. The first readings of the fall of the charged leaf were taken thirty seconds after the gas delivery was stopped. In this case no decrease in activity was observed during the first two minutes of observation. Hence thorium emanation was absent. In the course of ten minutes the leak increased about 12 per cent, which is characteristic of radium emanation. The gas evidently was relatively rich in emanation, as the leak was fully 1,000 times the usual air leak of the instrument. Our field journal shows that 60 small divisions of the scale were passed over by the leaf in eleven and six-tenths seconds. After twelve minutes of observation the gas was blown out and the electroscope set aside for a time to wait for the 


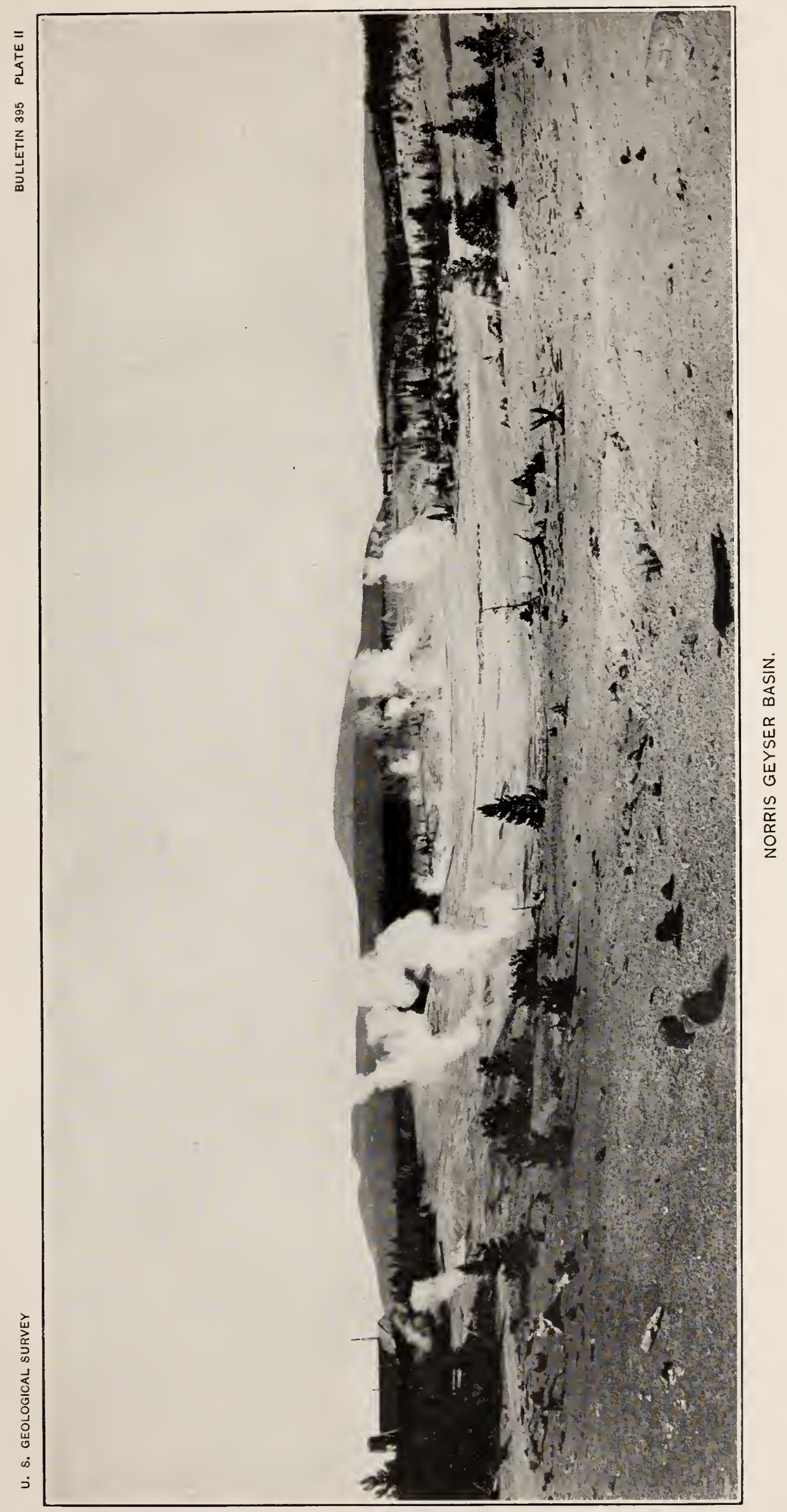



decay of the induced activity. Later in the day a quantitative determination of the radium emanation present in the escaping gas was made with the same electroscope. Ninety cubic centimeters of gas were collected over water (temperature $40^{\circ} \mathrm{C}$.) and introduced into the partially exhausted electroscope. At maximum activity the leaf fell 23.6 small scale divisions per minute after deducting the normal air leak, which was 0.2 division per minute. The volume of the gas sample reduced to normal temperature and pressure is 56.3 cubic centimeters. $^{a}$ In this electroscope a leak of one division per minute represented $2.8 \times 10^{-4}$ grams uranium or $10.64 \times 10^{-11}$ grams radium. The activity of the gas per liter, in terms of the uranium standard, is hence expressed by the following equation:

$$
\frac{23.6 \times 2.8 \times 10^{-4} \times 1,000}{56.3}=117 \times 10^{-3} .
$$

Expressed in terms of the radium standard the activity equals $117 \times 10^{-3} \times 3.8 \times 10^{-7}=44.5 \times 10^{-9}$.

The value of the ionization current per liter of gas, in electrostatic units, is obtained by substituting in the formula:

$$
\mathrm{i}=\frac{\mathrm{q} \times \mathrm{c} \times 1,000}{300 \times \mathrm{t} \times 56.3} \text {. }
$$

For $q$ may be put the potential fall in volts during the interval of time ( $\mathrm{t}$ ) expressed in seconds, and $\mathrm{c}$ is the electric capacity of the electroscope. Since each division of the scale represents 1.24 volts, and the capacity is 2.81 centimeters, the numerical equation for the value of the ionization current is:

$$
\frac{23.6 \times 1.24 \times 2.81 \times 1,000}{300 \times 60 \times 56.3}=81.2 \times 10^{-3} \text { electrostatic units. }
$$

For the determination of the activity of the water from this spring, the water gas separated from a sample of 2,570 cubic centimeters was introduced into electroscope No. 2. This sample of water was collected in the immediate vicinity of the orifices from which the gas issued. The maximum net leak observed was 10.9 scale divisions per minute. The activity of the water sample, per liter, in terms of the uranium standard, is given by the equation:

$$
\frac{10.9 \times 7.7 \times 10^{-4}}{2.57}=32.6 \times 10^{-4} \text {. }
$$

This value is equivalent to $1,238 \times 10^{-12}$ grams radium. The numerical equation for the ionization current in electrostatic units has the form:

$$
\frac{10.9 \times 2.80 \times 3.51}{300 \times 60 \times 2.57}=2.33 \times 10^{-3}
$$

$a$ In reducing the observed gas volumes to those for normal conditions the value 600 millimeters was used for the barometric pressure in all the calculations. Correction was of course made for the aqueous tension. 
The water sample upon evaporation left a residue weighing less than 2 grams. Its radium content was too small to be determined in so small a quantity of material. It therefore follows that the activity of the water is temporary in nature, and that the dissolved radium emanation did not come directly from the radium salts carried in solution. The greater portion of the emanation doubtless diffused into the water from the radium-bearing rocks with which the water came in contact in the course of its underground flow.

\section{RADIOACTIVITY OF GASES.}

The names of the gas sources in Table 2 are those found in the atlas accompanying Monograph 32 of the United States Geological Survey, entitled "Geology of Yellowstone Park." The locality names in the second column of the table are also the official names. Names inclosed in quotation marks are not official. The third column shows whether thorium emanation was detected in the qualitative field test. In some instances the activity due to thorium is compared with that observed for radium. In the last column the activity values are recorded in both the uranium and the radium standards. They represent the radium emanation present per liter of gas. The blank spaces indicate that no test was conducted.

TABLE 2.--Radioactivity of gases in Yellowstone Park.

MAMMOTH HOT SPRINGS.

\begin{tabular}{|c|c|c|c|c|}
\hline \multirow[b]{2}{*}{ Name of source. } & \multirow[b]{2}{*}{ Location. } & \multirow{2}{*}{$\begin{array}{l}\text { Thorium } \\
\text { emana- } \\
\text { tion. }\end{array}$} & \multicolumn{2}{|c|}{ Radium emanation. } \\
\hline & & & $\begin{array}{c}\text { Uranium } \\
\text { (grams } \\
\left.\times 10^{-3}\right)\end{array}$ & $\begin{array}{c}\text { Radium } \\
\text { (grams } \\
\left.\times 10^{-9}\right) .\end{array}$ \\
\hline 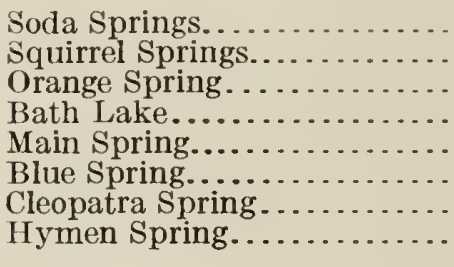 & 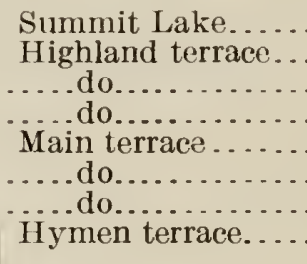 & $\begin{array}{l}\text { None. } \\
\text { None. } \\
\text { None. } \\
\text { None. } \\
\text { None. } \\
\text { None. } \\
\text { None. }\end{array}$ & $\begin{array}{r}1.5 \\
7.5 \\
\text { Trace. } \\
\text { Trace. } \\
\text { None. } \\
\text { None. } \\
\text { None. } \\
\text { None. }\end{array}$ & 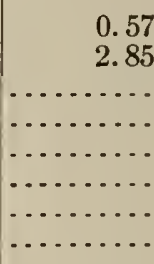 \\
\hline
\end{tabular}

NORRIS GEYSER BASIN.

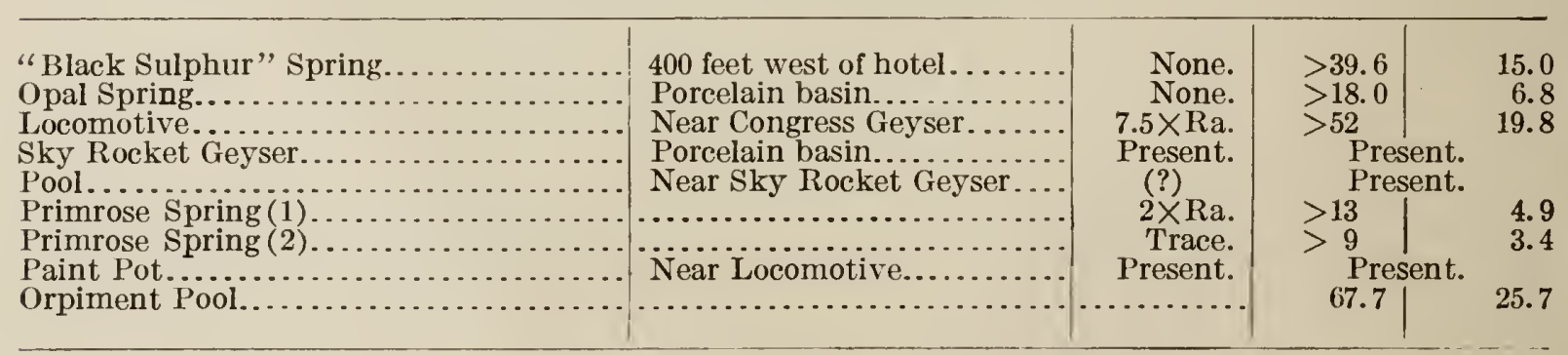


TABLE 2.-Radioactivity of gases in Yellowstone Park-Continued.

LOWER GEYSER BASIN AND TERRACE SPRINGS.

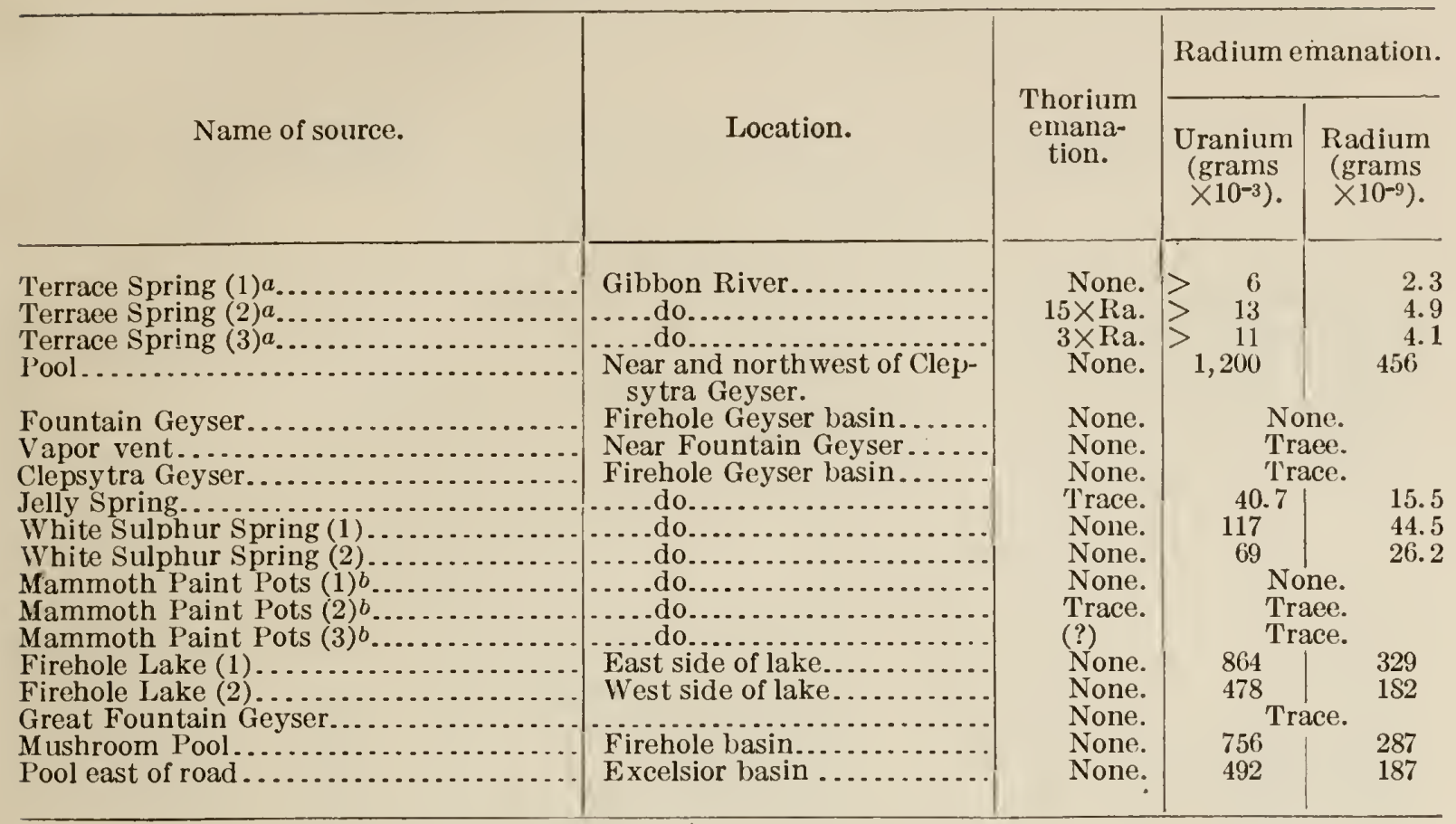

UPPER GEYSER BASIN.

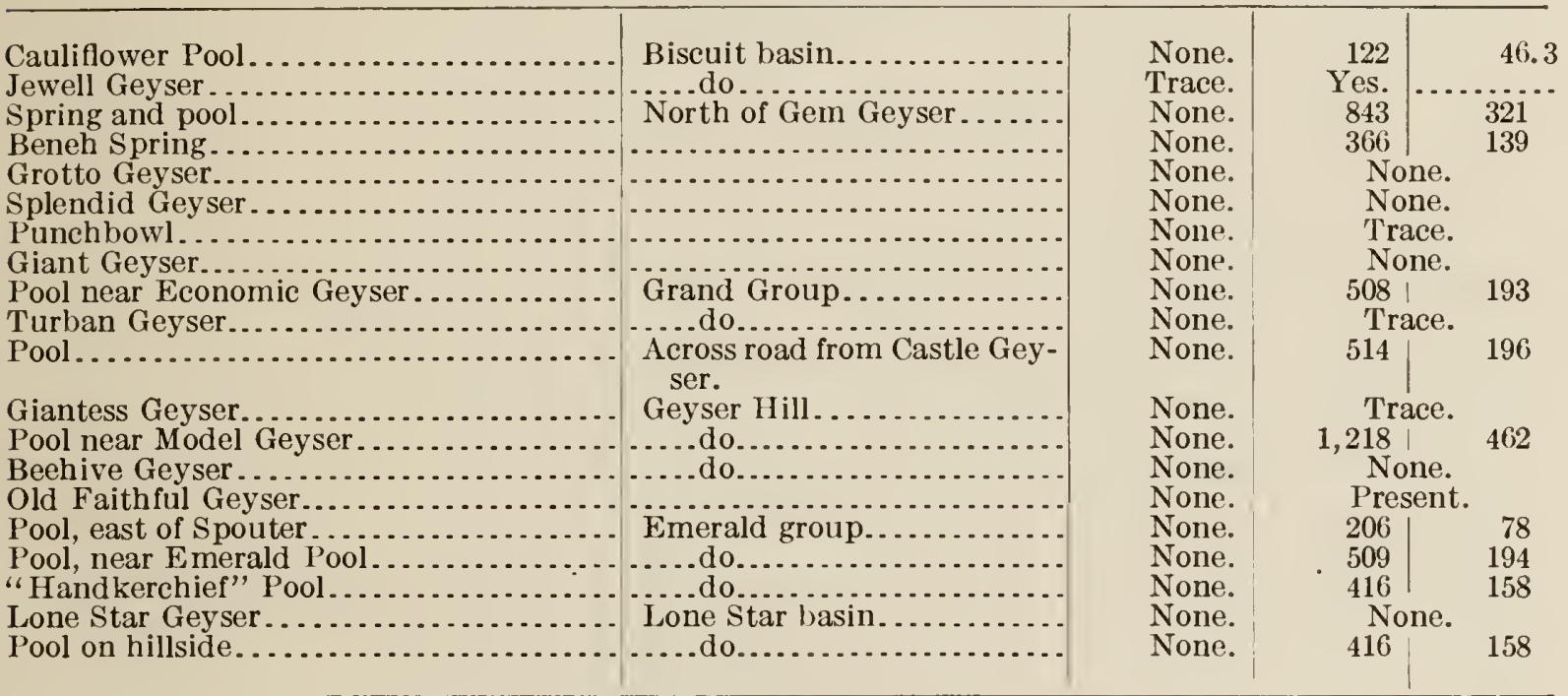

SHOSHONE GEYSER BASIN.

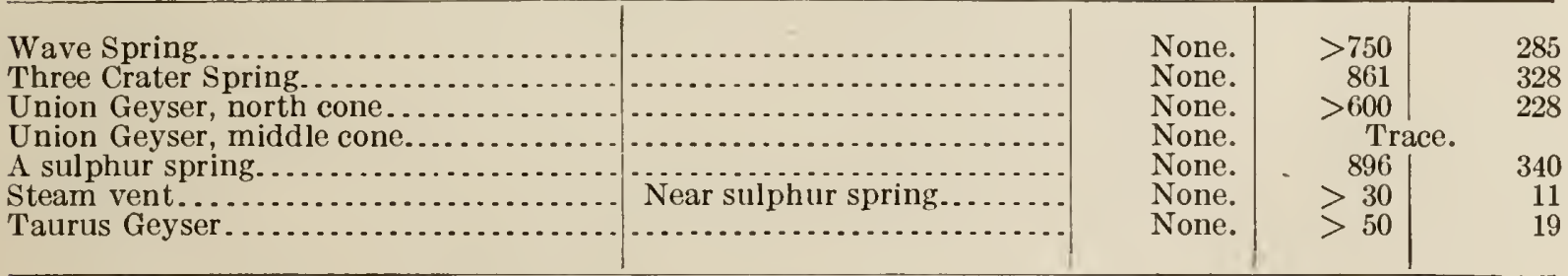

HEART LAKE, GEYSER BASIN.

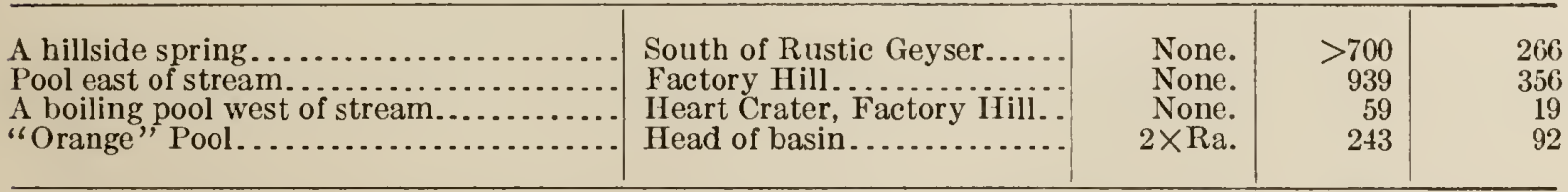

$a$ Terrace Spring No. 1 is the lowest one on the terraees. It discharges large quantities of gas; No. 3 is on the third terrace; the volume of gas discharged from Nos. 2 and 3 is relatively small; less gas eseapes from No. 2 than No. 3.

$b$ Test 1 on the west side of the group; No. 2 on the south side, and No. 3 on the east side. 
TABLE 2.-Radioactivity of gases in Yellowstone Park-Continued.

WEST THUMB, YELLOWSTONE LAKE.

\begin{tabular}{|c|c|c|c|c|}
\hline \multirow[b]{2}{*}{ Name of source. } & \multirow[b]{2}{*}{ Yocation. } & \multirow{2}{*}{$\begin{array}{c}\text { Thorium } \\
\text { emana- } \\
\text { tion. }\end{array}$} & \multicolumn{2}{|c|}{ Radium emanaton. } \\
\hline & & & $\begin{array}{c}\text { Uranium } \\
(\text { grams } \\
\left.\times 10^{-3}\right)\end{array}$ & $\begin{array}{l}\text { Radium } \\
\text { (grams } \\
\left.\times 10^{-9}\right)\end{array}$ \\
\hline Pool west of road. & One mile from military post. & None. & 382 & \\
\hline Pool east of road.. & ... do $\ldots$. & None. & 45 & 17 \\
\hline Yellowstone Lake. & Boat pier ........... & None. & 266 & 107 \\
\hline Paint Pot........... & Near lunch station. & Present. & $>150$ & 51 \\
\hline Pool near Paint Pot. & Lunch station..... & $\left\{\begin{array}{c}\text { Equal to } \\
\text { Ra. }\end{array}\right.$ & 309 & 117 \\
\hline Fish Cone........... & ........ & None. & 123 & 47 \\
\hline
\end{tabular}

LOCALITIES ALONG YELLOWSTONE RIVER.

\begin{tabular}{|c|c|c|c|c|}
\hline Pool. & $\begin{array}{l}\text { South area of activity, mud } \\
\text { geysers. }\end{array}$ & None. & 49 & 18.6 \\
\hline Pool ................ & East of large mud geyser... & None. & 155 & 59 \\
\hline $\begin{array}{l}\text { Yellowstone River. } \\
\text { Steam and gas vent. }\end{array}$ & East of Camp Howard..... & None. & $7.6 \%$ & 2.9 \\
\hline Hellbroth Springs. . & $\begin{array}{l}\text { Mud geyscrs } \\
\text { Mount Wa........ }\end{array}$ & $4 \times \mathrm{Ra}$. & $>110$ & 42 \\
\hline Devil's Ink Pot... & $\ldots \ldots$ do & Present. & $>40$ & 15 \\
\hline Black Pool (1) : & $\begin{array}{l}\text { West side of formation, } \\
\text { Mount Washburn. }\end{array}$ & Present. & $>50$ & 19 \\
\hline $\begin{array}{l}\text { Black Pool (2).. } \\
\text { Nymph Spring. }\end{array}$ & $\begin{array}{l}\text { Mount Washburn. } \ldots \ldots \ldots \\
\text { Tower Falls............... }\end{array}$ & $(?)$ & $\begin{array}{l}17.2 \\
19.2\end{array}$ & $\begin{array}{l}6.5 \\
7.3\end{array}$ \\
\hline
\end{tabular}

\section{RADIOAC'TIVITY OF WATERS.}

The values recorded for the activities of the water samples in Table 3 are expressed in terms of both the uranium and the radium standards. They represent the radium emanation in a fresh sample of water. In several instances some time elapsed between the collection of the sample and the determination. In such tests correction was made for the decay in the activity of the sampies during the interval between the time of collecting and the time of testing by means of the formula $I_{0}=I_{t} e^{-r t}$, expressing the decay of activity with the time. $I_{o}$ represents the initial activity, $I_{t}$ the activity observed $t$ hours after the water was collected, and $r$ the radioactive constant of radium emanation. The value of $\mathrm{r}$ used in the calculations was 0.0077 , which is an approximate mean of the values found by several investigators. The temperatures given were taken with a normal centigrade thermometer graduated in degrees. The instrument was not self-registering. At some of the springs it was difficult to get accurate readings, as the hot water and vapors interfered materially with readings at close range. For the most part the values recorded are correct to within half a degree. As the reaction of the waters to litmus paper was tested, the results are recorded in a separate column. This table, like the preceding one, is subdivided on the basis of the more important localities. Several of the names recorded are not found on the maps of the United States Geological Survey. Most of 
these, however, are probably the official names, as they appear on the printed signboards. New names are inclosed with quotation marks. We aimed to include the spring waters of the park analyzed by Gooch and Whitfield. ${ }^{a}$

TABLe 3.-Radioactivity of waters in Yellowstone Park.

MAMMOTII HOT SPRINGS.

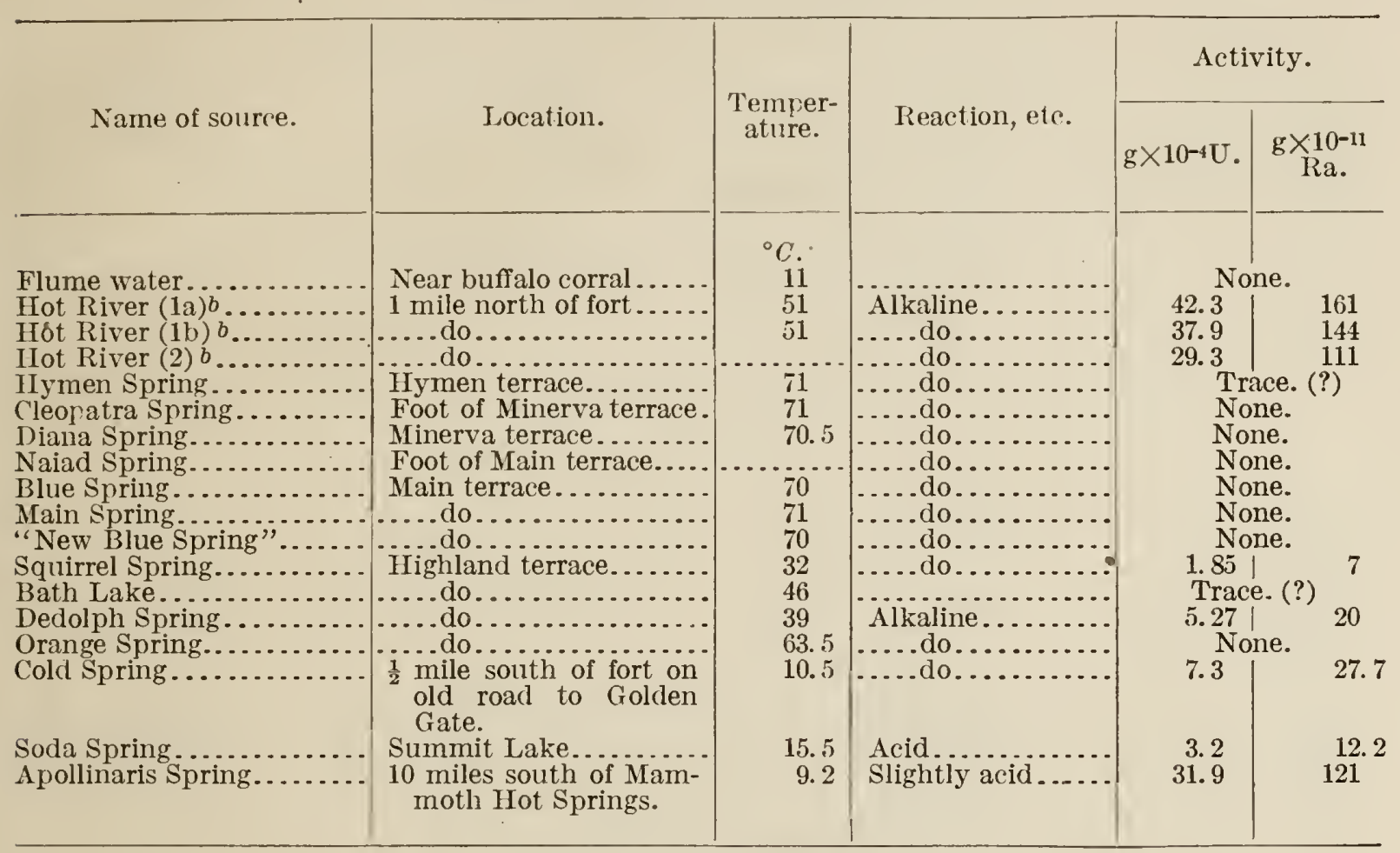

NORRIS GEYSER BASIN.

\begin{tabular}{|c|c|c|c|c|c|}
\hline "Iron" Spring. . . . . . . . . & Solfatara Creek......... & 15 & Faintly alkaline... & 13. 1 & $\begin{array}{r}\text { 1. } 3 \\
49.7\end{array}$ \\
\hline A thermal spring.......... & $\begin{array}{l}\text { Near Iron Spring and } 1 \\
\text { mile north of post on } \\
\text { trail. }\end{array}$ & 50.5 & Neutral.......... . & 1. 9 & 77.2 \\
\hline A cold spring............ & $\begin{array}{l}1 \text { mile east of Norris on } \\
\text { road to canyon. }\end{array}$ & 16 & & 17.5 & 66.5 \\
\hline Gibbon River. & & & & & \\
\hline An iron spring ............. & ...do do. $_{\text {. }}$ & . & & 18.7 & 71 \\
\hline Realgar Spring........... & 100-spring plain ......... & _... & & 10.6 & 40.5 \\
\hline The reservoir . . . . . . . . . . & . . . do . . . . . & 71 & Slightly acid. & 6.9 & 26.5 \\
\hline "Black Sulphur" Spring.. & 300 feet west of hotel.... & 90 & & 4. 6 & 17.4 \\
\hline 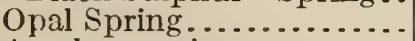 & Porcelain basin......... & 58 & Slightly acid. & 1.1 & 4. 2 \\
\hline Primrose Spring... & Near Nuphar Lake...... & 88 & & 1. 0 & 3.9 \\
\hline "Drab" Spring........... & Near Primrose Spring... & 89 & Strongly acid..... & 0.5 & 1.9 \\
\hline A cold spring.............. & $6 \frac{1}{2}$ miles south of Norris, & & & 2.05 & 7.8 \\
\hline A carbonated spring.. & $\begin{array}{l}8 \text { miles south of Norris, } \\
\text { by roadside. }\end{array}$ & (c) & & 9.0 & 34 \\
\hline
\end{tabular}

$a$ Bull. U. S. Geol. Survey No. 47: 1888.

$b$ Samples 1a and $1 \mathrm{~b}$ were collected where the main current of Hot River first issues from the rock. Test $1 \mathrm{a}$ was made July 15,$1906 ; 1 \mathrm{~b}$, the following day. Sample 2 was taken from a small hot stream that empties into Gardiner River about 60 rods upstream from the mouth of Hot River. c Cold. 
TABLE 3.-Radioactivity of waters in Yellowstone Park-Continued. LOWER GEYSER BASIN.

\begin{tabular}{|c|c|c|c|c|c|}
\hline \multirow[b]{2}{*}{ Name of source. } & \multirow[b]{2}{*}{ Location. } & \multirow{2}{*}{$\begin{array}{l}\text { 'Temper- } \\
\text { ature. }\end{array}$} & \multirow[b]{2}{*}{ Reaction, etc. } & \multicolumn{2}{|c|}{ Activity. } \\
\hline & & & & $\mathrm{g} \times 10^{-4} \mathrm{U}$ & $\underset{\mathrm{Ra}}{\mathrm{g} \times 10^{-11}}$ \\
\hline A cold spring...... & $\begin{array}{l}4 \text { miles north of Foun- } \\
\text { tain hotel near road- } \\
\text { side. }\end{array}$ & ${ }^{\circ} \mathrm{C}$. & & 8.2 & 31 \\
\hline $\begin{array}{l}\text { Lower spring .......... } \\
\text { Middle spring...... }\end{array}$ & $\begin{array}{l}\text { Terrace Springs } . . . . . . \\
. . . \text { do }\end{array}$ & $\begin{array}{l}63 \\
40\end{array}$ & Slightly alkaline. & $\begin{array}{l}5.3 \\
2.4\end{array}$ & $\stackrel{20}{9.1}$ \\
\hline Hygeia Spring . . . & Near army post & 53 & (ndo & Tr & \\
\hline Fountain Geyser $a$. & Near cleosvtra Gevser & $\begin{array}{l}88 \\
85\end{array}$ & ..... do . . . & No & ne. \\
\hline White Sulphurspring & Near Fountain Geyser.. & 59 & . . do . & 32.6 & $\begin{array}{r}62 \\
121\end{array}$ \\
\hline $\begin{array}{l}\text { Firehole Lake......... } \\
\text { Mushroom Pool. }\end{array}$ & Near Great Fountain & $\begin{array}{l}85 \\
75\end{array}$ & ... do... & $\begin{aligned} 8.5 \\
10\end{aligned}$ & $\begin{array}{l}32 \\
38\end{array}$ \\
\hline Pool............. & $\begin{array}{l}\text { Geyser. } \\
\text { East of road, Excelsior }\end{array}$ & 6.5 & & 34.7 & 131 \\
\hline Excelsior Geyser. & Excelsior basin ........ & 92 & Slightly alkaline. & & ce. \\
\hline
\end{tabular}

UPPER GEYSER BASIN.

Cauliflower Pool.

Firehole River.............

Spring...................

Bench Spring...........

Asta Spring.............

Old Faithful Geyser........

Pool and spring...........

$$
\text { Do .. }
$$

Spring..................

II andkerchief Pool ........

A mountainside spring ....

"Reservoir" Spring ......

$\Lambda$ roadside spring.

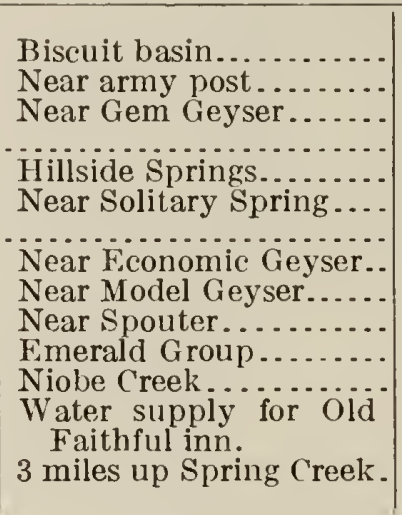

\begin{tabular}{|c|c|}
\hline 61 & Neutral. \\
\hline 64 & Faintly acid. . \\
\hline $\begin{array}{l}86 \\
86\end{array}$ & Faintly alkaline. \\
\hline 52 & …. \\
\hline 81 & Neutral.. \\
\hline 82 & Alkaline. \\
\hline $\begin{array}{l}70 \\
82\end{array}$ & Faintly alkaline.. \\
\hline 13 & . do ............ \\
\hline 31 & Neutral. \\
\hline 10.5 & ....do. . \\
\hline
\end{tabular}

6.5 Trace.

70.5 268

\begin{tabular}{l|r}
6.4 & 24 \\
8.45 & 24
\end{tabular}

8. 45032

26.5 101

23.9

6.1

8.1

4. 8

67.5

11.2

14.9

91
23
31
13
256
42.5
56.5

\section{SHOSHONE GEYSER BASIN.}

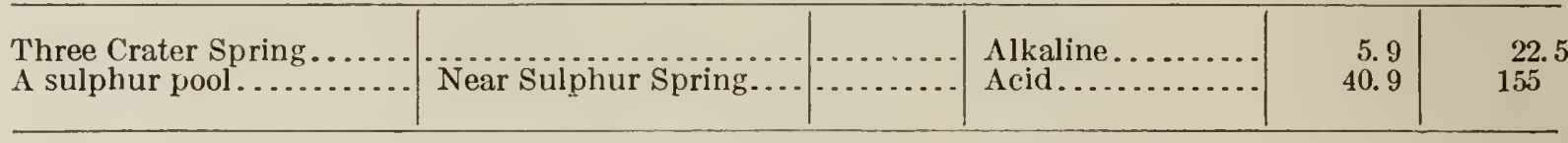

IIEART LAKE GEYSER BASIN.

\begin{tabular}{l|l|l|l|r|r}
\hline Pool and spring........... & $\begin{array}{l}\text { Near Rustic Geyser............. } \\
\text { "Orange" Plkaline......... }\end{array}$ & $\begin{array}{r}19.1 \\
4.7\end{array}$ & $\begin{array}{r}72.5 \\
\text { Strongly acid..... }\end{array}$ \\
\hline
\end{tabular}

WEST THUMB, YELLOWSTONE I.AKE.

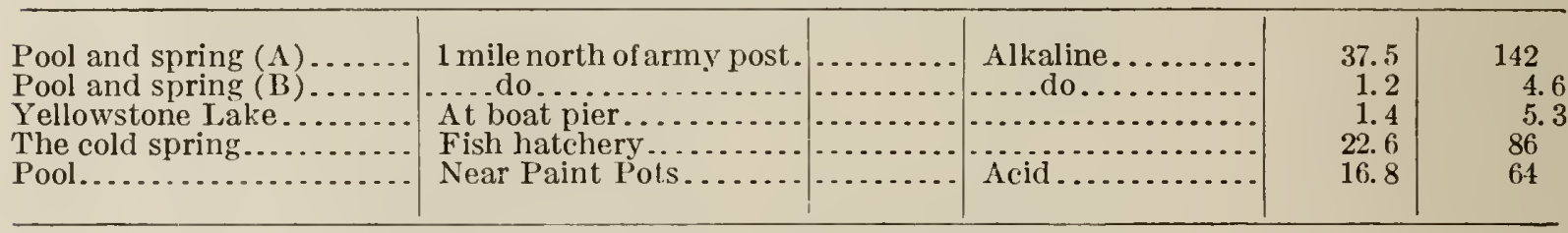

\section{YELLOWSTONE RIVER LOCALITIES.}

\begin{tabular}{|c|c|c|c|c|}
\hline Yellowstone River. & Camp Howard......... & Neutral........ & None. & \\
\hline Pool and spring.... & $\begin{array}{l}\text { Mud Geysers; south } \\
\text { basin of activity. }\end{array}$ & Acid.......... & 15.1 & 57 \\
\hline Do & East of Mud Geyser..... & $d$ & & 207 \\
\hline Chrome Spring. & Sulphur Mountain. ..... & & None. & \\
\hline A hot spring... & Foot of lower falls, can- & & 3. 0 & 11.4 \\
\hline Forest Hill Springs & 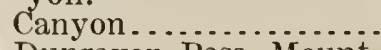 & Acid & 6.35 & 24.2 \\
\hline A cold spring & $\begin{array}{l}\text { Dunraven Pass, Mount } \\
\text { Washburn. }\end{array}$ & & 10.3 & 39 \\
\hline Devi & Mount Washburn....... & Acid & .6 & 2.3 \\
\hline Nymph Spring & Tower Falls.. & Nentral.. & 6.9 & 26.3 \\
\hline
\end{tabular}


RADIOACTIVITY OF WATER RESIDUES, SPRING DEPOSITS, AND ROCK SAMPLES.

The values given for the activities of solids in Tables 4, 5, and 6 , represent the radium present per gram of the air-dry material. The quantity of material taken in each determination is recorded in the third column of the tables. The samples in Table 4 are water residues; those in Table 5 are incrustations deposited by the springs where the water issues. The samples were collected for the most part at the time the water samples were tested, and the radium was determined during the years 1906 and 1907 . Several samples of travertine at Mammoth Hot Springs were collected by Capt. William II. Forsythe, U. S. Army. Some of the rock samples from typical formations in the park were obtained from the collection of the United States Geological Survey through the kindness of Dr. Arnold Hague.

TABle 4.--Radioactivity of water residues, Yellowstone Park.

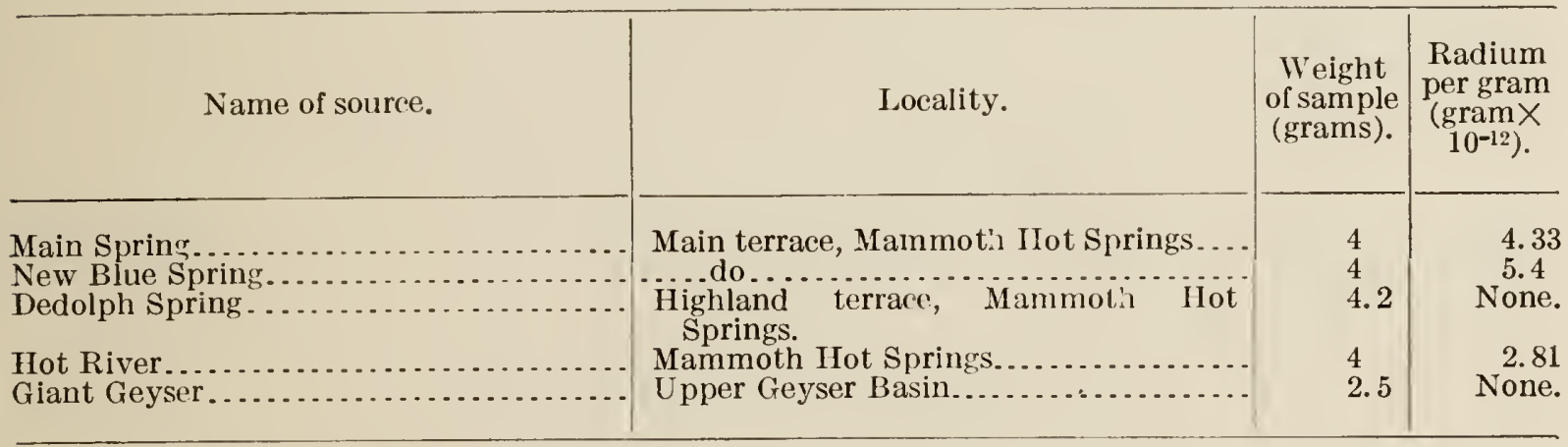

TABLE 5.-Radioactivity of spring deposits, Yellowstone Park.

MAMMOTH HOT SPRINGS.

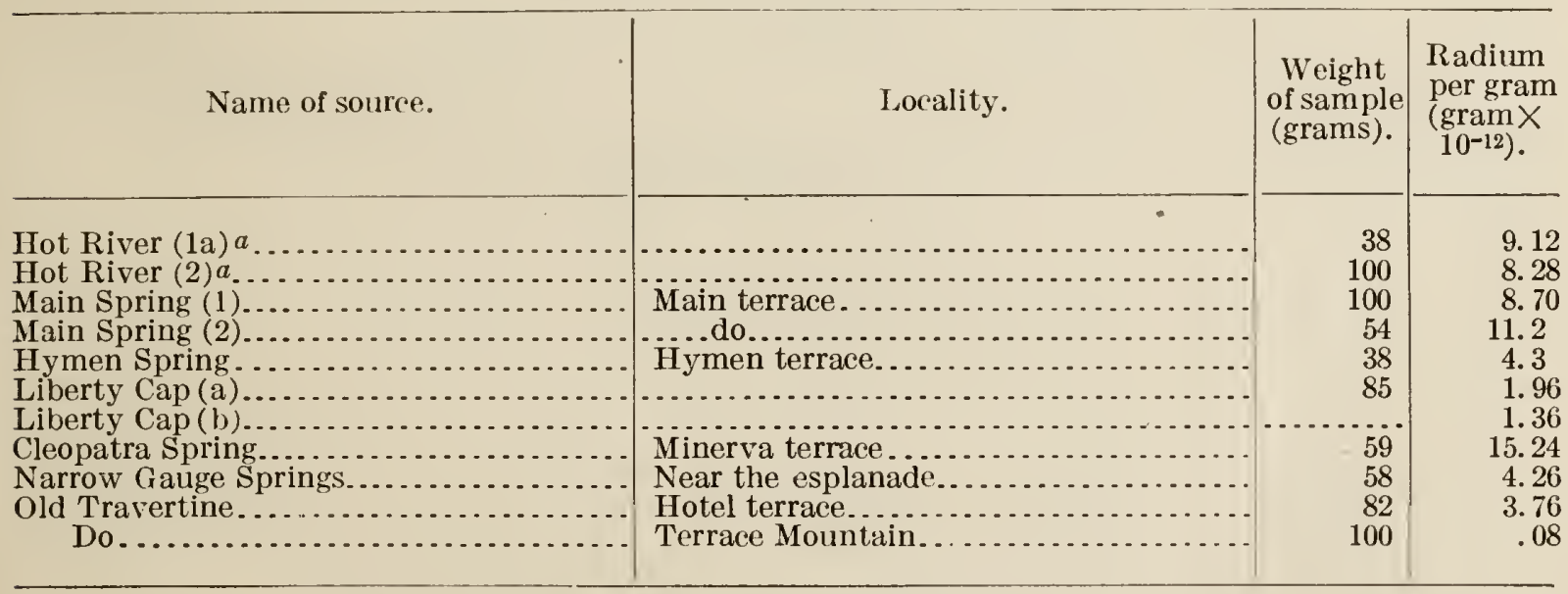

NORRIS BASIN.

\begin{tabular}{|c|c|c|c|}
\hline Opal Spring .................. & 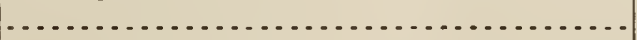 & 30 & .31 \\
\hline Paint Pot ${ }_{1} \ldots \ldots \ldots \ldots \ldots \ldots$ & . & 30 & 2.39 \\
\hline 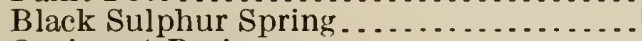 & 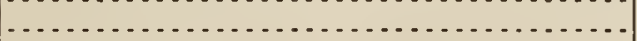 & 30 & 1.40 \\
\hline Orpiment Pool ...................... & $\ldots \ldots \ldots \ldots \ldots \ldots \ldots \ldots$ & 30 & .59 \\
\hline Paint Pot (Artists) . . . . . . . . . . . & 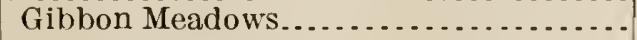 & 50 & 3.57 \\
\hline
\end{tabular}

$a$ Sample 1a is from main stream; No. 2 is from small outlet. 
TABle 5.-Radioactivity of spring deposits, Yellowstone Park-Continued.

LOWER GEYSER BASIN.

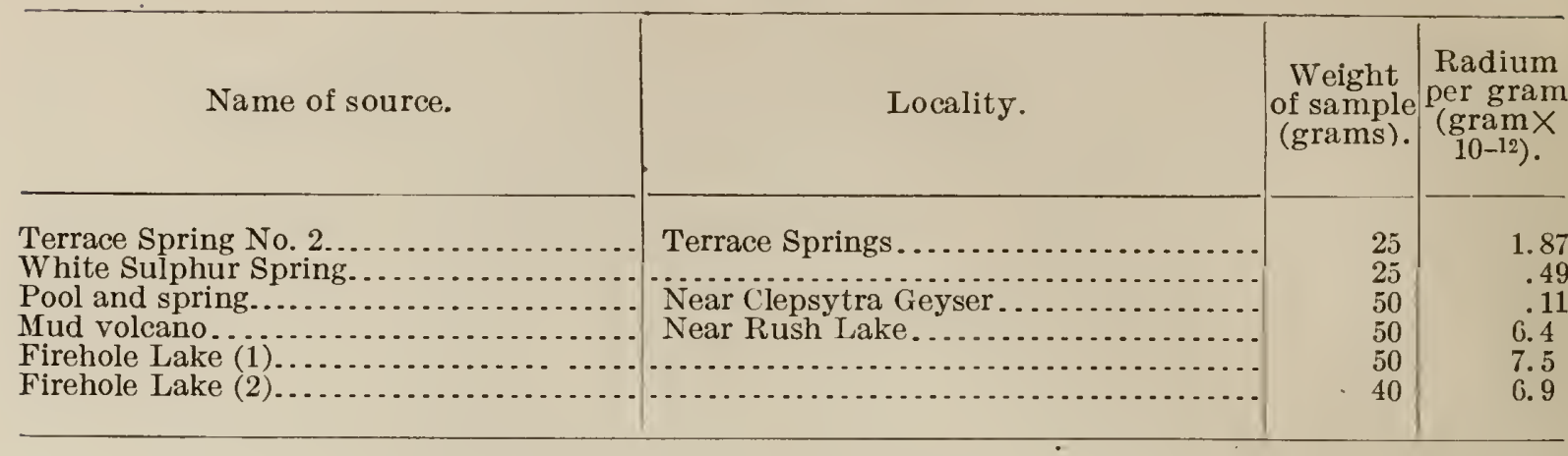

UPPER GEYSER BASIN.

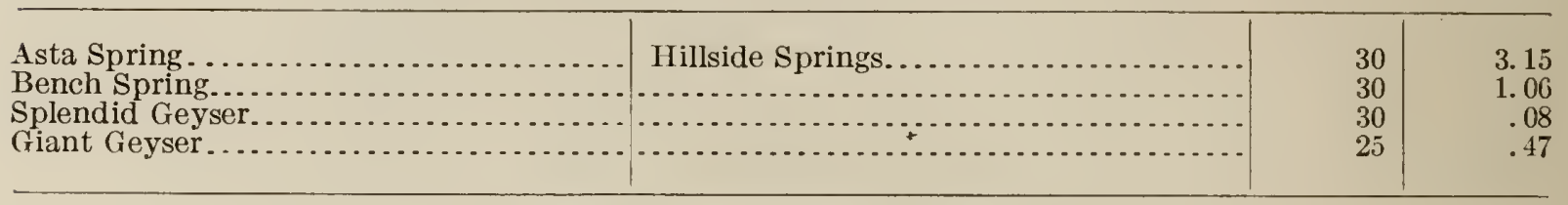

SHOSHONE GEYSER BASIN.

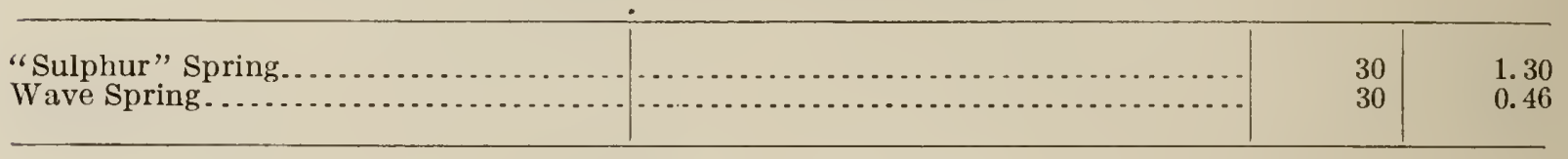

HEART LAKE GEYSER BASIN.

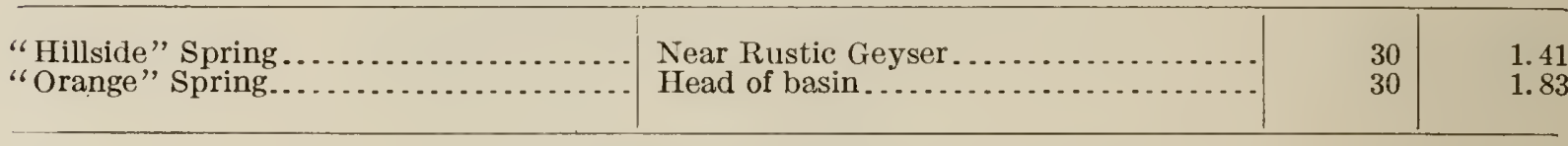

WEST THUMB, YELLOWSTONE LAKE.

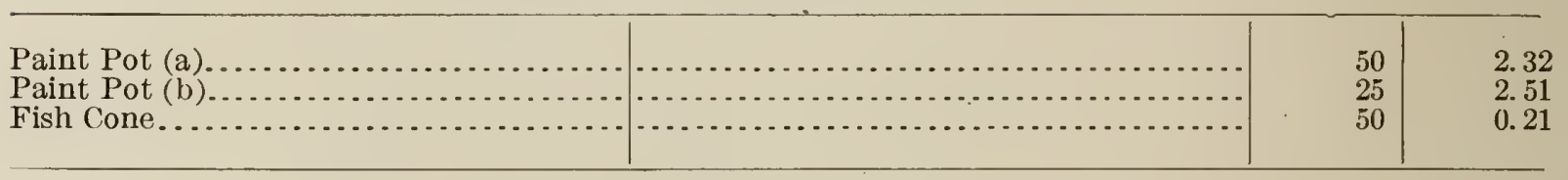

YELLOWSTONE RIVER LOCALITIES.

Mud Geyser.

Devil's Ink Pot

Forest Springs..

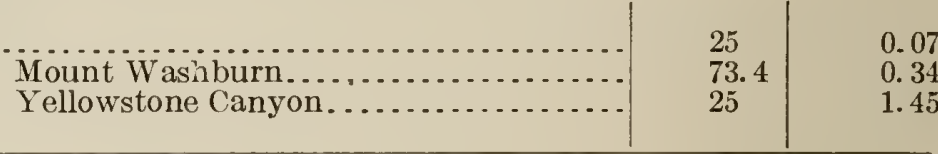

Table 6.-Radioactivity in rock samples, Yellowstone Park.

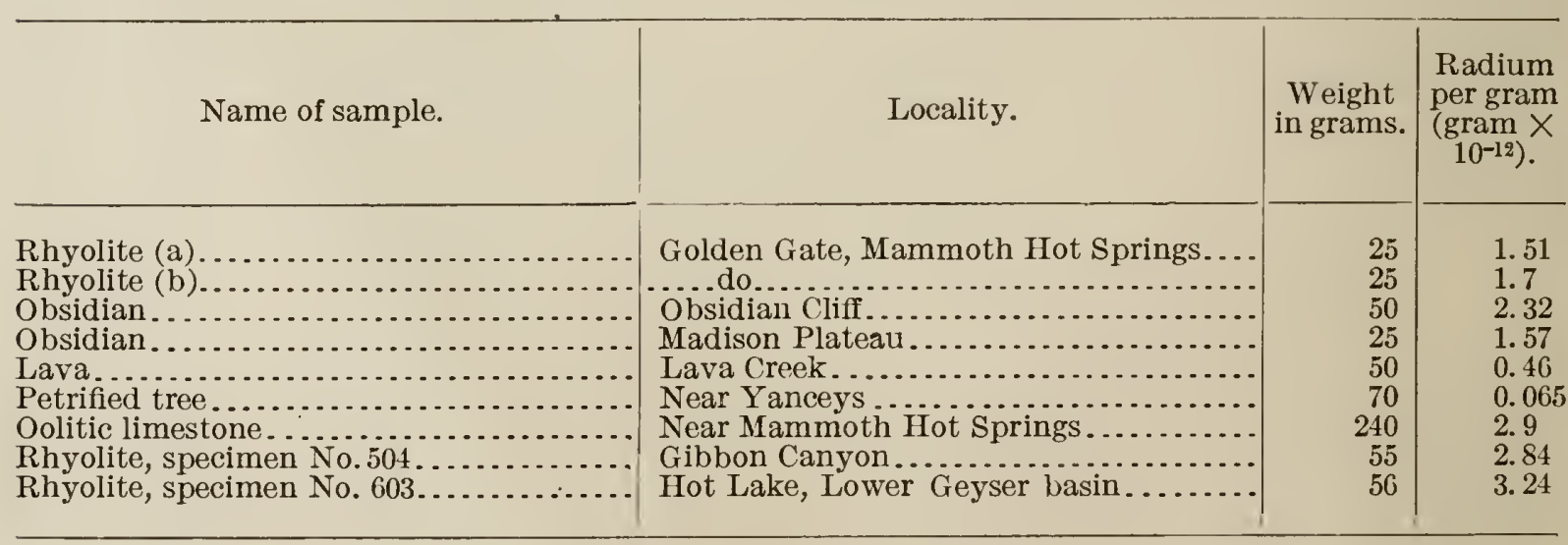


SUMMARY OF RADIOACTIVITIES.

To facilitate comparisons, most of the results presented in the foregoing tables are summarized in Table 7 . The values are expressed in terms of the radium standard.

TABLE 7.-Summary of radioactivities of gases, waters, and deposits in Yellowstone Park.

MAMMOTH HOT SPRINGS.

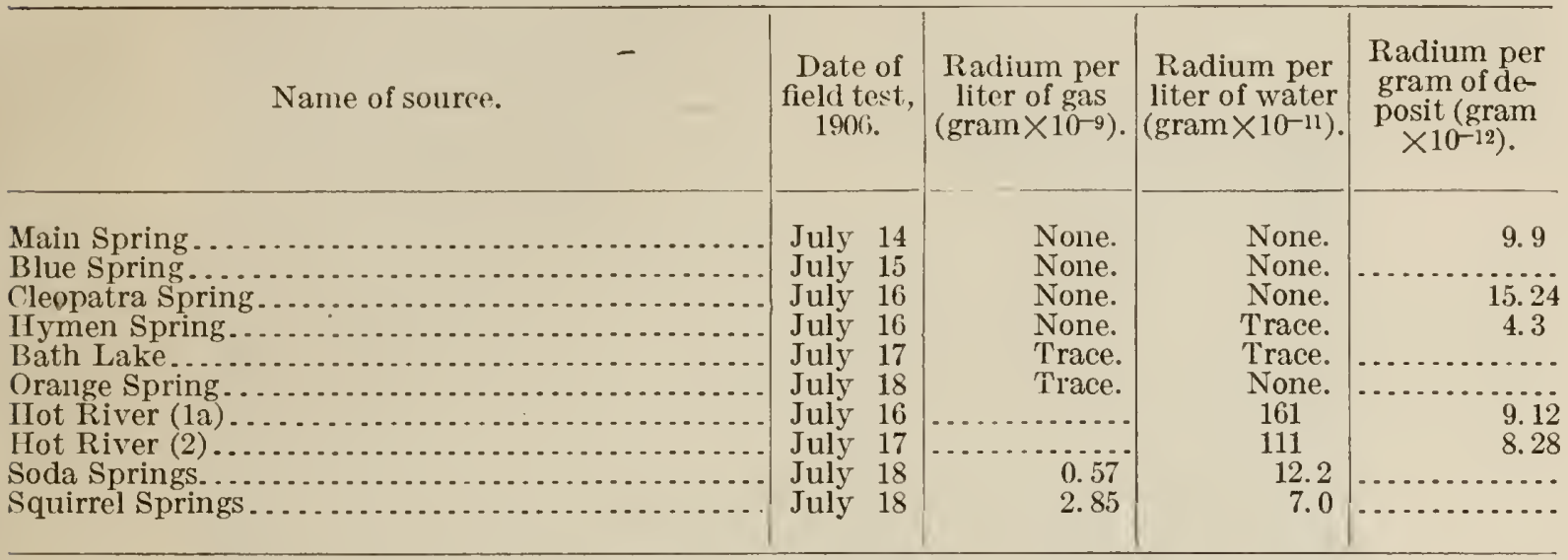

NORRIS GEYSER BASIN.

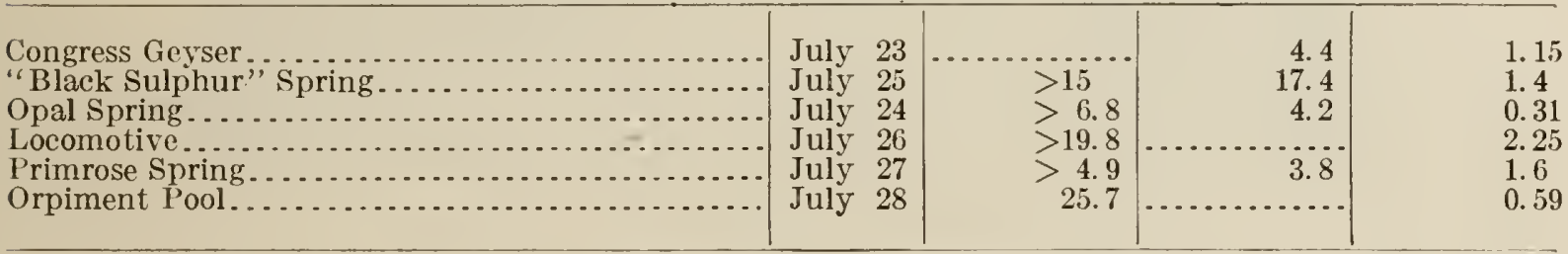

LOWER GEYSER BASIN.

\begin{tabular}{|c|c|c|c|c|}
\hline Fountain Geyser........ & July* 30 & None. & None. & $\ldots .$. \\
\hline 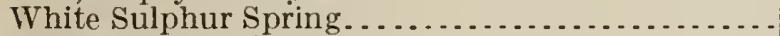 & Aug. 1 & 44.5 & 138 & 0.49 \\
\hline Firehole Lake $(1) \ldots \ldots \ldots$ & Aug. 3 & 329 & 32 & 7.5 \\
\hline Firehole Lake $(2) \ldots \ldots$ & Aug. 3 & 182 & & 6. 9 \\
\hline 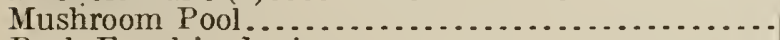 & Aug. 5 & 287 & 38 & ............. \\
\hline
\end{tabular}

UPPER GEYSER BASIN.

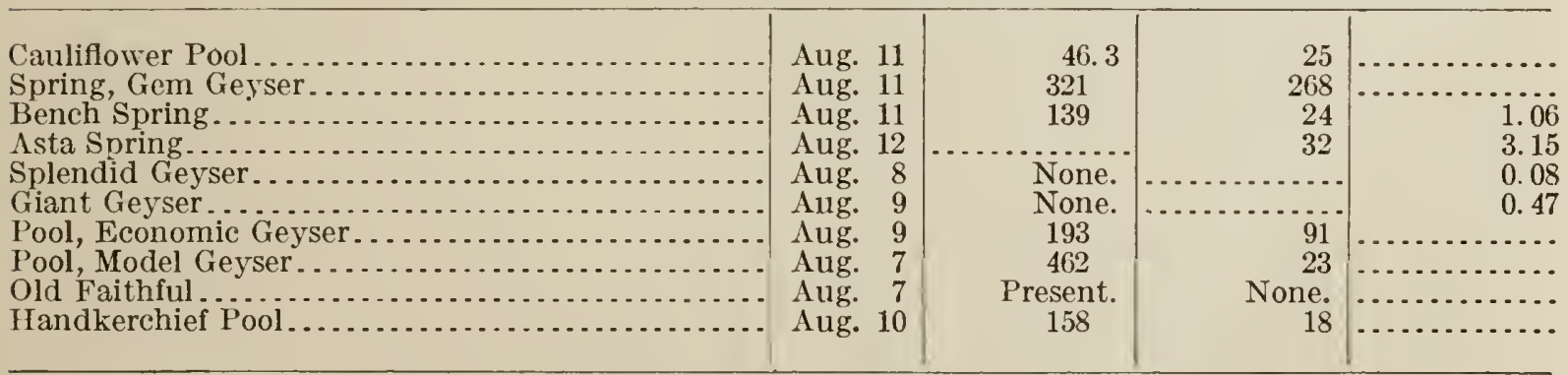

SHOSHONE GEYSER BASIN.

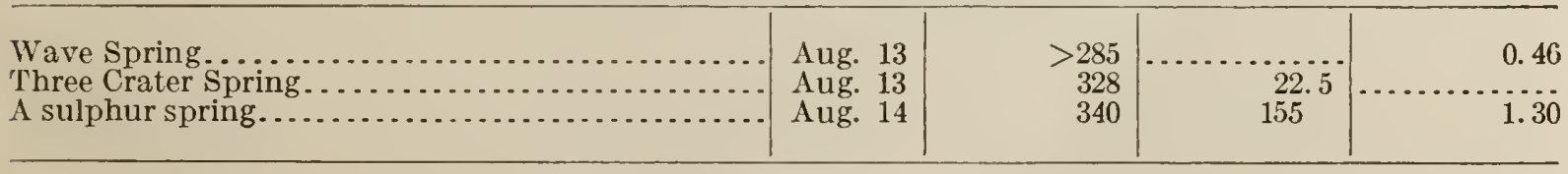

HEART LAKE GEYSER BASIN.

\begin{tabular}{|c|c|c|c|c|}
\hline $\begin{array}{l}\text { Hillside Pool, Rustic Geyser } \ldots \ldots \\
\text { Orange Pool. } \ldots \ldots\end{array}$ & Aug. 21 & $>266$ & 72.5 & 1.42 \\
\hline Orange Pool............ & Aug. 22 & & 17.8 & 1.83 \\
\hline
\end{tabular}


TABLE 7.-Summary of radioactivities of gases, waters, and deposits in Yelloustone Park-Continued.

WEST THUMB, YELLOWSTONE LAKE.

\begin{tabular}{|c|c|c|c|c|}
\hline Name of source. & $\begin{array}{c}\text { Date of } \\
\text { field test, } \\
1906 .\end{array}$ & $\begin{array}{l}\text { Radium per } \\
\text { liter of gas } \\
\left(\text { gram } \times 10^{\circ}\right) .\end{array}$ & $\begin{array}{l}\text { Radium per } \\
\text { liter of water } \\
\left.\text { (gram } \times 10^{11}\right) \text {. }\end{array}$ & $\begin{array}{l}\text { Radium per } \\
\text { gram of de- } \\
\text { posit (gram } \\
\left.\times 10^{12}\right) \text {. }\end{array}$ \\
\hline 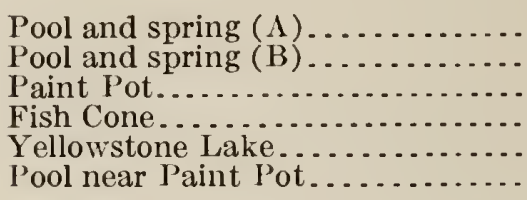 & $\begin{array}{l}\text { Aug. } 17 \\
\text { Aug. } 17 \\
\text { Aug. } 19 \\
\text { Aug. } 18 \\
\text { Aug. } 17 \\
\text { Aug. } 18\end{array}$ & $\begin{array}{r}145 \\
17 \\
>57 \\
47 \\
101 \\
117\end{array}$ & $\begin{array}{c}72.5 \\
4.6 \\
\cdots \\
7.3 \\
54\end{array}$ & $\begin{array}{c}\ldots \ldots . \\
\ldots .32 \\
0.21 \\
\ldots \ldots .\end{array}$ \\
\hline
\end{tabular}

YELLOWSTONE RIVER LOCAIATIES.

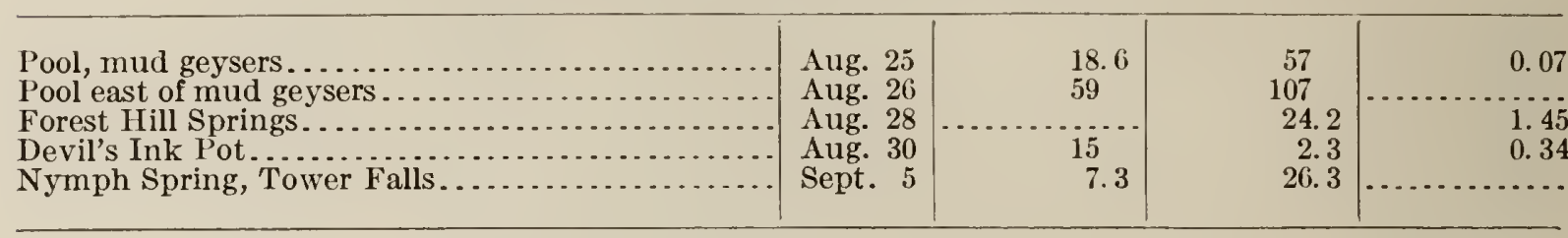

\section{DISCUSSION OF RESULTS.}

GAS ACTIVITIES.

Thorium emanation.-The tabulated results show that marked differences exist in the activity of gases from different springs. In most cases the activity is due entirely to radium emanation. In at least 16 of the 82 gas sources examined thorium emanation was found associated with that of radium. These are the first springs on this Continent which to our knowledge have been found to contain thorium emanation, and the number reported in Europe is small. The initial activity due to thorium emanation varied from a mere trace to fifteen times that due to radium emanation in the same gas. Owing to the rapid rate of decay of the thorium emanation the results relative to it are only approximately quantitative and represent the minimum quantity. The thorium emanation was most marked at Norris Geyser basin and at Terrace Springs near the mouth of Gibbon River. Thorium emanation was not found alone in any gas. Some radium emanation always accompanied it. Actinium emanation was looked for, but without success. Its extremely rapid rate of decay (half value in four seconds) makes its detection difficult in small amounts under field conditions.

Relative activity.-In only one of the ten localities visited in the park were the escaping gases found, on the whole practically inactive. This locality is the well-known group of springs in the northern part of the park, known as Mammoth Hot Springs. Since the volume of the escaping gases from these highly carbonated waters is relatively large, this fact probably accounts for the extremely low concentration of the emanation in the gases and waters of this locality. In this connection it should be mentioned that the most active gas recorded (pool near Model Geyser, Upper Geyser basin) issued very 


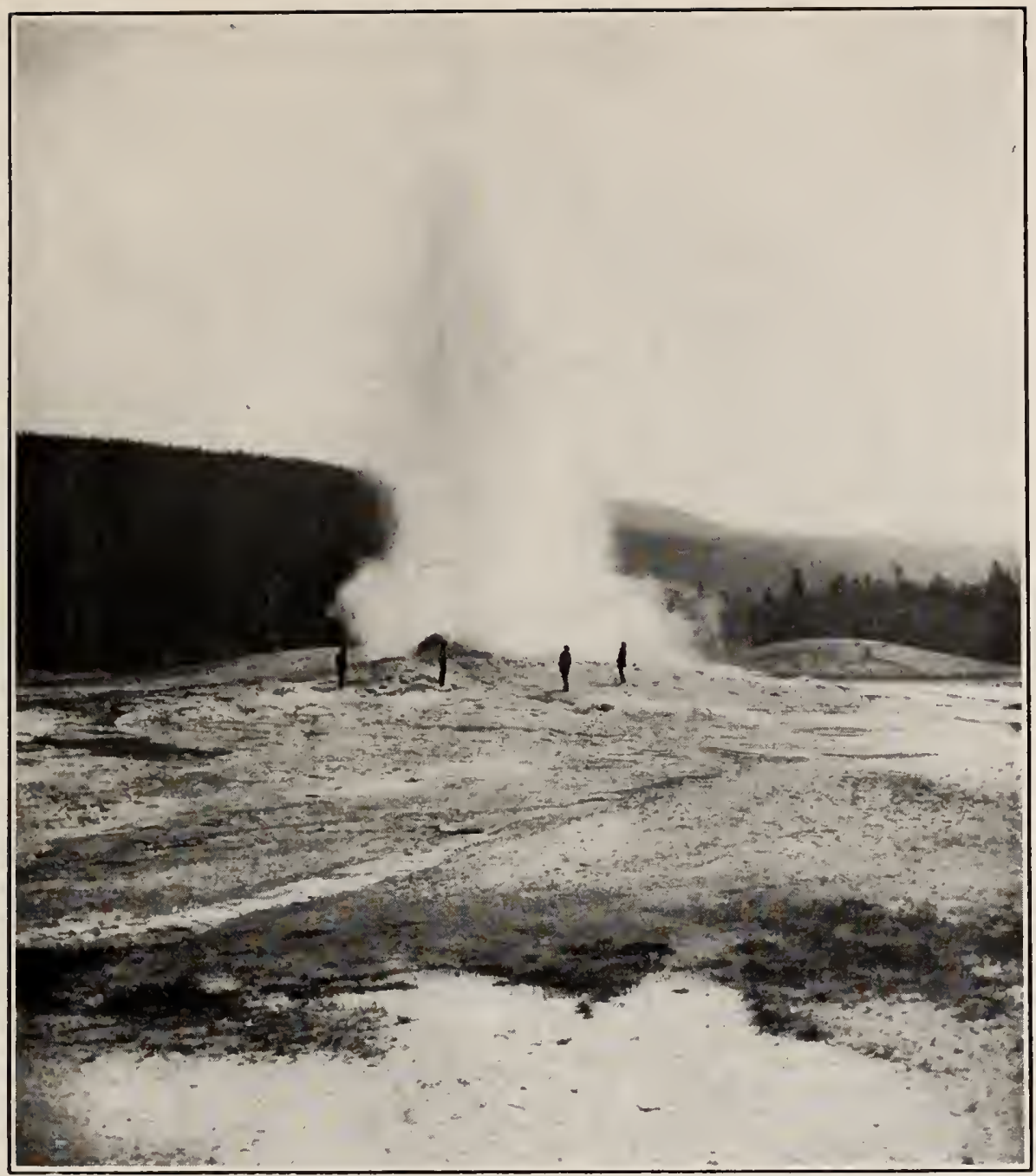

A. OLD FAITHFUL GEYSER, UPPER GEYSER BASIN.

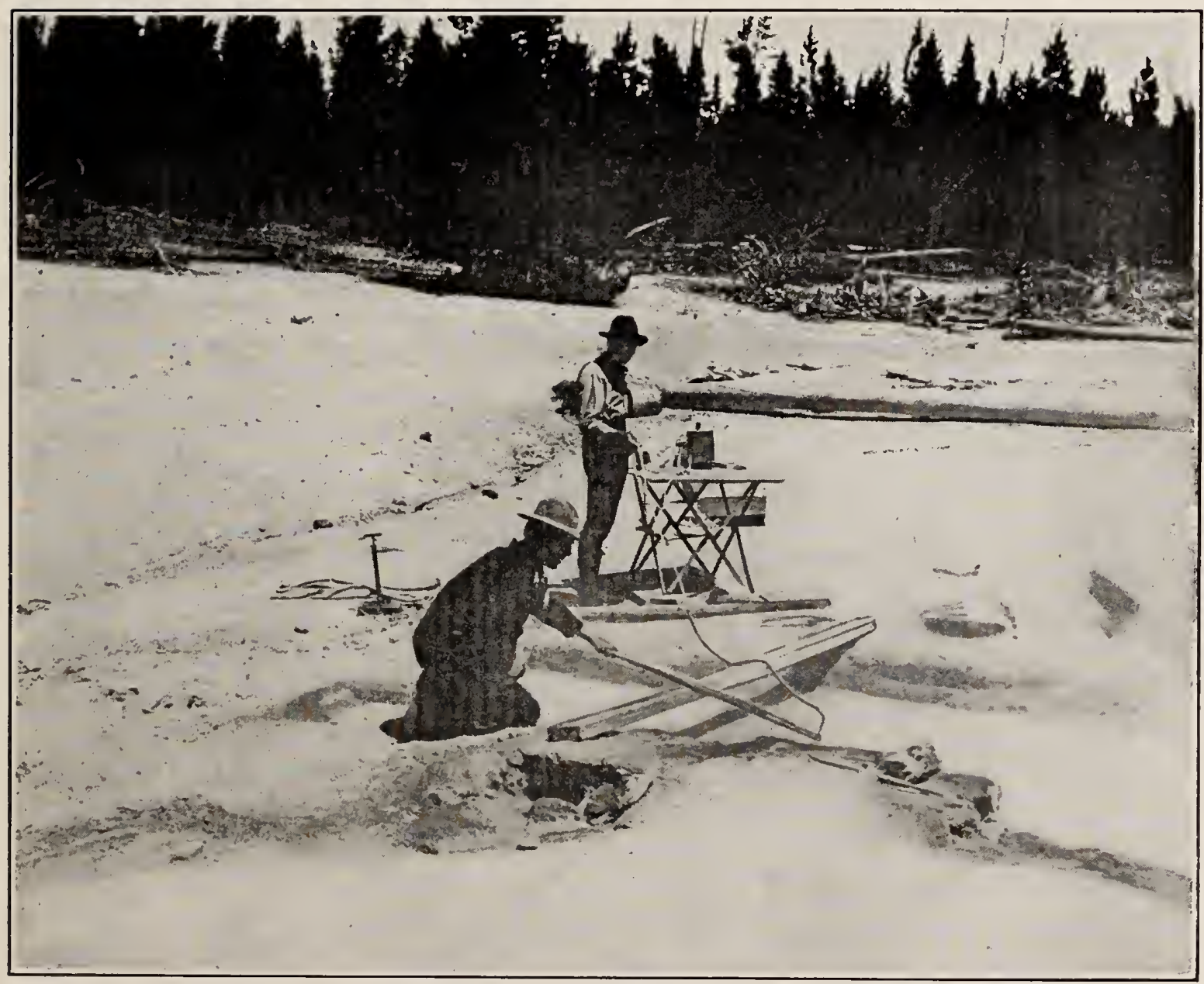

B. HOT SPRING, NORRIS GEYSER BASIN, WHERE THORIUM WAS FIRST DISCOVERED IN THE UNITED STATES 

slowly, and that the next most active gas (pool near Clepsytra Geyser, Lower Geyser basin) required nearly an hour for the collection of a sample of 50 cubic centimeters in a bottle having a mouth 3 centimeters wide. The latter spring gives the appearance of discharging gas freely, but most of the bubbles proved to be steam.

Gases from European springs.- Some of the well-known thermal and cold springs on the European Continent are more or less charged with gases, like many of those of Yellowstone Park. The radioactive properties of the gases escaping from the European springs have been extensively studied by different investigators, and numerous quantitative results are thus available for comparison. The following table gives representative data for gases from springs in various European localities and for different localities in Yellowstone Park. The values for the activity in the third column of the table are expressed in electrostatic units.

TABLE 8.-Radioactivity of gases from springs in Europe and in Yellowstone Park.

\begin{tabular}{|c|c|c|c|}
\hline Name of source. & Location. & $\begin{array}{c}\text { Activity } \\
\text { (electro- } \\
\text { static units, } \\
\left.\mathrm{I} \times 10^{3}\right)\end{array}$ & Observer. \\
\hline Grabenbäcker Quelle................ & Gastein................... & 564 & Mache. $a$ \\
\hline Elizabeth Stollen. . . . . . . . . . . & . do & 412 & Do. \\
\hline 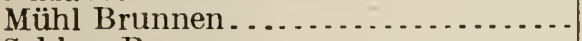 & Karlsbad..................... & 94.2 & Mache and Meyer.b \\
\hline 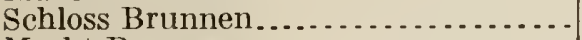 & .....do...... & 50.2 & Do. \\
\hline 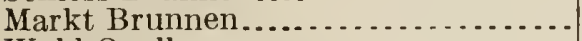 & . . do & 1.51 & Do. \\
\hline 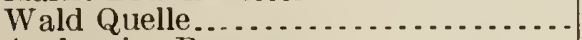 & Marienbad................ & 10.9 & Do. \\
\hline Ambrosius Brunnen................ & do $\ldots$ do . . . . . & 1.48 & Do. \\
\hline 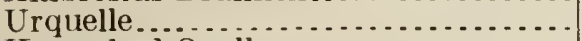 & Teplitz-Schönau............ & 21.9 & Do. \\
\hline Herrenbad Quelle................. & Fischau................. & 2.18 & Mache and Meyer.c. \\
\hline Haupt Quelle....................... & do .................. & 2.60 & Do. \\
\hline Johannabad . . . . . . . . . . . . . . & Baden . . . . . . . . . . . . . & 16.6 & Do. \\
\hline Vauquelin ... . . . . . . . . & Plombières............... & 184 & Curie and Laborde. $d$ \\
\hline 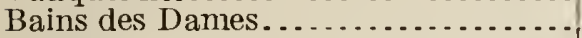 & Luxeuil. . . . . . . . . . . . & 23 & Do. \\
\hline Chomel . . . . . . & Vichy $\ldots . . .6$. & 18 & Do. \\
\hline Viktoria Brunnen ............... & Oberlahnstein.......... & 1.25 & Borne.e \\
\hline Schützenhof Quelle............. & Wiesbaden ............... & 50 & Henrich. $f$ \\
\hline Orpiment Pool..................... & Norris basin $\ldots$ & 47 & Schlundt and Moore. \\
\hline Firehole & Lower Geyser basin....... & 600 & Do. \\
\hline Spring and pool near Clepsytra Geyser. & 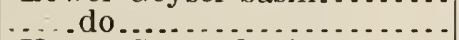 & 834 & Do. \\
\hline 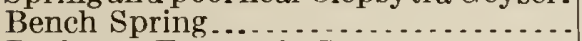 & Upper Geyser basin . . . . . . & 254 & Do. \\
\hline Pool near Economic Geyser........... & 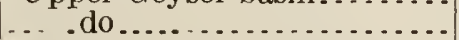 & 353 & Do. \\
\hline Three Crater Spring ...................... & Shoshone Geyser basin..... & 598 & Do. \\
\hline 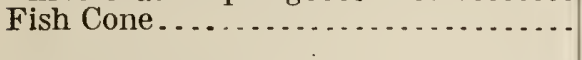 & West Thumb, Yellowstone & 85 & Do. \\
\hline Nymph Spring. & Tower Falls............ & 13.3 & Do. \\
\hline
\end{tabular}

$a$ Sitzungsber. K. Akad. Wiss., Wien, Abt. 2a, vol. 113, p. 1329.

$b$ Idem, vol. 114, p. 355 .

$c$ Idem, vol. 114, p. 545 .

$d$ Compt. Rend., vol. 138, p. 1150

$e$ Jahrbuch Radioak., vol. 2 , p. 77.

$f$ Sitzungsber. K. Akad. Wiss., Wien, Abt. 2a, vol. 113, p. 1092.

Although the values for the activity as given by different observers are based upon somewhat different systems of reckoning (some investigators, Mache, for example, do not include the ionization effect of the disintegration products), still the values given show that the gases from the springs in Yellowstone Park are fully as active as those from European sources.

Helium not determined.-In several of the more active Europenn springs it is known that helium is one of the constituents of the escaping gas. No tests were made by us to ascertain the presence of 
helium in any of the gases tested. The marked radioactive properties of the gases from many of the springs would make an examination of the gases for helium and the other rare gases very desirable.

\section{ACTIVITI OF WATERS.}

Inferences from different results. - The tabulated results clearly show that the thermal waters in different localities and even in the same locality differ considerably in activity. In some samples.no activity was detected. Several cold springs were also tested. These likewise showed marked differences in activity, and their average somewhat exceeds that of the thermal springs. It is evident then that the temperature of the waters is independent of their activity. Similar variations in activity were found by Boltwood ${ }^{a}$ in his extensive tests of the radioactive properties of the waters of Hot Springs, Ark., and by us in connection with the examination of some natural waters of Missouri. ${ }^{b}$ The acidity or alkalinity of the water seems to have no connection with its activity.

Is the activity of the waters due to radium emanation which has diffused into them in the course of their underground flow, or is it produced by the radium that the waters carry in solution? As those water residues which were examined yielded only traces of radium emanation, we may conclude that the radium salts in solution are responsible for only a small part of the total activity, most of which is due to radioactive gases that have diffused into the water's.

Some of the differences observed in the activities are readily explained. The water of boiling springs and therefore of geysers almost invariably gave negative tests. Such a temperature is not favorable for the retention of dissolved gases. The escaping steam and the consequent agitation of the waters are both effective in removing any radioactive gases that may have been absorbed by the water.

The same effect may be caused in another way. If a large volume of gas is evolved from a spring, whose temperature may lie considerably below the boiling point, the emanation is swept out of the water by the gas. Such a condition also is not favorable for the accumulation of radioactive gases. In such a spring the activity of the gas also will prove to be low, although a considerable amount of emanation may have been removed by it. If these conditions were not considered such a spring might be classified as inactive, though its residue on evaporation might be found to contain appreciable quantities of radium. Most of the springs tested at Mammoth Hot Springs are examples of this condition. All of the springs on the Main Terrace gave negative results for both waters and gases, within the limits of error of our instruments under field conditions, and yet the residues and deposits, as Tables 4 and 5 show, greatly exceed in 
activity those of springs in other localities, the waters of which were found to be radioactive in a marked degree.

At all events the results for waters and gases show that the underlying rock in the park contains radium and in some localities thorium in sufficient quantities to make the waters and gases decidedly radioactive.

Comparison with European waters.-The radioactive properties of European thermal and mineral waters have been studied extensively by different investigators. From the numerous quantitative data a few have been selected and arranged in tabular form. Some of the values obtained by Boltwood in his examination of the waters of Hot Springs, Ark., are incorporated in the table, as well as values obtained for some Yellowstone Park waters.

'TABLE 9.-Radioactivity of spring waters in Europe and in the United States.

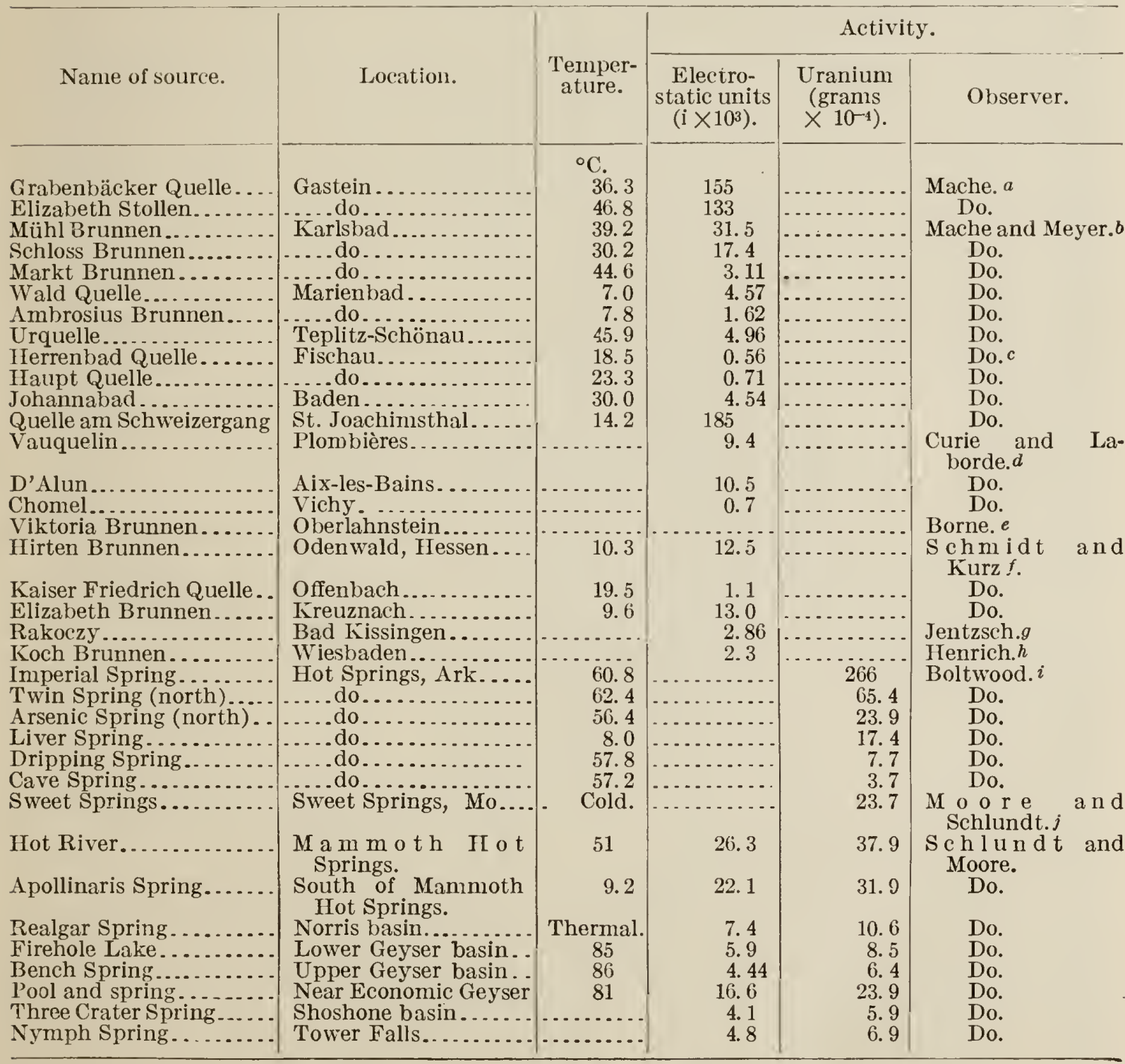

$a$ Sitzungsber. K. $\Lambda$ kad. Wiss., Wien, Abt. 2a, vol. 113, p. $13 \varepsilon 9$.

$b$ Idem, vol. 114, p. 355 .

$c$ Idem, vol. 114, p. 545 .

$d$ Compt. Rend., vol. 142,1906, p. 1462.

e Jahrbuch Radioak, vol. 2, p. 77.

$f$ Phys. Zeitschr., vol. 7, 1906, p. 214

g Idem, vol. 8, 1907, p. 887

$h$ Sitzungsber. K. Akad. Wiss., Wien, Abt. 2a, vol. 113, p. 1092

$i$ Am. Jour. Sci., vol. 20, 1905, p. 128.

jTrans. Am. Electrochem. Soc., vol. 8. p. 291. 
A comparison of the activities of the thermal waters of Yellowstone Park with those of European springs, as given by the foregoing table, shows that with a few exceptions the quantity of radium emanation carried is of the same order of magnitude and that marked variations exist. It is seen that the European springs in localities where deposits of pitchblende occur are distinctly more radioactive. In making comparisons of this kind, however, it must be borne in mind that the temperature of most of the park waters is near the boiling point, and that this factor is unfavorable for the accumulation of the emanation. It is worthy of note, in this connection, that the gases escaping from many of the springs in the park contain about the same quantity of radium emanation as the most active European thermal springs, which are located in regions where extensive deposits of radioactive minerals occur. It is therefore probable that many of the park waters traverse radium-bearing minerals in the course of their underground flow.

The waters of Hot Springs, Ark., are probably fully as active as those of the park, but their temperatures average considerably lower. The gases rising from two of the springs at Hot Springs were found by Boltwood ${ }^{a}$ to be less active than equal volumes of gases separated from the waters by boiling, a result in direct contrast with our observations on the thermal springs of the park.

A discussion of the results in the foregoing table with respect to the hydrography of the different localities lies beyond the scope of this paper.

\section{RADIUM CONTENT OF DEPOSITS AND ROCKS.}

Comparative activity of different rocks.-At Mammoth Hot Springs the waters are calcareous, the dissolved material being derived from the underlying Jurassic and Cretaceous. At the other basins the waters are siliceous (some alkaline, some acid), the dissolved material being derived from the rhyolite of which the park plateau is largely formed. In both classes of deposits radium was detected.

The deposits of travertine at Mammoth Hot Springs contain radium in appreciable quantities. The activity of the residue obtained by evaporating the water is about half that of the deposits, showing that the radioactive material is largely deposited with the components that come out of solution first. This fact alone would account in a large measure for moderate differences in the radium content of the deposits formed by different springs of similar origin. The values obtained at Mammoth Hot Springs for the radium content of the deposits from the actively flowing springs, however, are of the same order of magnitude. The radium content of these deposits averages about $8 \times 10^{-12}$ grams per gram of material, a value two and one-half times greater than the 


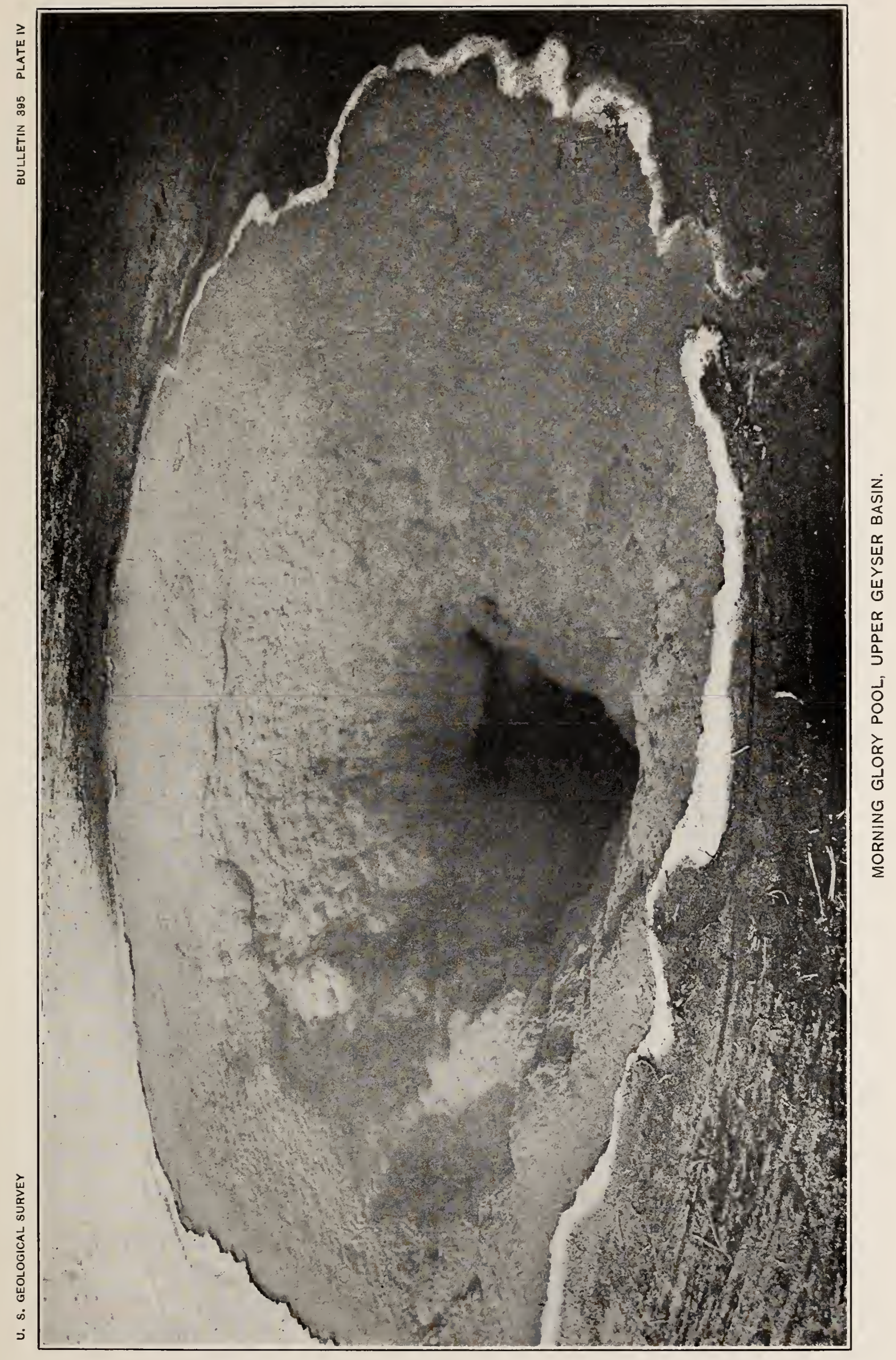



radium content of the rock from which the deposits are probably derived, and about five times the average radium content of the ioneous rock of the park. To account for the concentration of radium in these spring deposits more experimental work is necessary. An investigation of the solvent action of hot, carbonated water on radiumbearing rock samples at different pressures might throw some light on the question. Again, the fact that radium in the Mammoth Hot Spring deposits is largely deposited with the components that first come out of solution may be connected with the numerous growths of algæ in these hot waters, which may act as precipitating reagents.

The siliceous deposits from some of the springs in the other basins of thermal activity likewise show a higher radium content than the igneous rock of the vicinity. In some cases the content is several times greater, but this result is not general. In fact, the nearly pure silica deposits from most of the geysers and the older springs contain less than half as much radium as the underlying rhyolite. The location of the springs appears to be related to the radium content of the residue. The residues with a radium content greater than that of adjoining rocks come, as a rule, from relatively new springs which are close to the outcropping rock. The disintegrated rock material from the so-called mud pots, paint pots, and mud volcanoes were also found to contain more radium than the park rhyolite.

Radioactive equilibrium.-Another question naturally arises in this connection: Is the radium thus deposited in radioactive equilibrium with its parent uranium? Some experimental evidence obtained indicates that far less uranium is deposited than the radium content requires. Of course, the quantity of uranium considered here is too small to be detected by chemical analysis, but if radium were present in the equilibrium ratio the activity of the deposits would remain practically constant for years. Now, the radium present in the old terraces, long since dry, is considerably below the average value for the recent deposits. A sample of travertine from Terrace Mountain, the scene of the first hot-spring activity at Mammoth Hot Springs, contains only about 1 per cent of the radium found in the present-day deposits of Jupiter terrace and Main terrace. Again, a sample of travertine from Hotel terrace, on which the government fort and buildings stand, carried only about 40 per cent of the radium found in most of the present-day deposits. Of course, these results might possibly be attributed to loss of radioactive material through weathering; but the hypothesis that radium and uranium are not deposited in radioactive equilibrium also furnishes a satisfactory explanation for the fact.

Estimate of age of deposits.-If we start with a given quantity of radium, separated from its parent uranium, at the end of 2,600 years, SSS65-Bull. 395-09-3 
according to recent determinations, one-half of it would be transformed into inactive products, at the end of another such period there would be only one-fourth of the original amount, and so on. If we assume, then, that the uranium deposited with the radium is far below the equilibrium quantity, the experimental results obtained follow. Moreover, from the data thus in hand the approximate age of the old deposits can be calculated. The application of these data to the question of the age of the deposits of course involves the assumption that the original radium content of the travertine in the old terraces was approximately the same as in the new. Such an assumption is not far from the truth. The similarity of the waters of this locality as a whole in regard to their radioactive content, as well as in other respects, is very close and indicates a common origin. Moreover, some of the old terraces are well within the zone of present activity. The travertine of Terrace Mountain is overlain by glacial bowlders. Since its activity is only 1 per cent of that of the recent deposits, its age is about 20,000 years, ${ }^{a}$ which would also be the approximate time that has elapsed since the glacial period in the park.

Comparative test for uranium by analysis.-Another line of experiments bearing on this question was suggested by some results obtained quite recently in determining the radium present in some of the "tufa" deposits made by the springs at Hot Springs, Ark. These deposits, like the travertine at Mammoth Hot Springs, are calcareous. The radium content ${ }^{b}$ of one of these deposits indicated the presence of about one-half of 1 per cent of uranium, a quantity well within the range of analytical methods. Investigation of the question from this standpoint would be of interest. The deposit in question, which was obtained from the Palace Spring, is three times as active as the famous Bath Springs of England tested by Strutt.

\section{RELATION TO HYDROTHERMAL ACTIVITY.}

Assuming that the thermal activity in the park is due to recent extrusive lava flow, or intrusive lava masses, the question arises to what extent the radium content of these rocks affects their rate of cooling. To what extent is the radium responsible for the continued hydrothermal activity? We have attempted no calculations with the data obtained from the Yellowstone Park rocks, for we do not know the volume of water discharged by these springs, and so lack data for calculating the heat dissipated by the water. At Hot Springs, Ark., the present flow from the springs is given by Haywood and Weed ${ }^{c}$ in their reports on the Hot Springs of Arkansas, at \$50,000

$a$ This would be 14,000 years if we accept 2,000 years as the half-time period of radium.

$b$ Trans. Am. Electrochem. Soc., vol. 12, 1907, p. 247.

c Haywood, J. K., Report of an analysis of the waters of the hot springs on the Hot Springs Reservation, Ark.; and Weed, W. H., Geological sketch of the IIot Springs district:57th Cong., 1st sess., S. Doc. No. 982 1902 pp. 31, 93. 
gallons daily. A simple calculation shows that the heat dissipated by the springs, flowing at the present rate during ten thousand years, would be furnished by approximately one cubic mile of solid lava cooling from its fusion point to the temperature of boiling water. Assuming that the radium present in the rocks is even somewhat greater than the average value found by $\operatorname{Strutt}^{a}$ and by us, for igneous rocks (say $5 \times 10^{-12}$ grams per gram of rock), the heat supplied by it per cubic mile of rock is about one-tenth of 1 per cent of the heat dissipated by the water.

The rock samples tested for radium gave values that average only a little more than Strutt's average for rhyolites and basalts-about $2 \times 10^{-12}$ grams radium per gram of rock. These data certainly seem to indicate that the hydrothermal activity so manifest in the park is not connected with localized deposits of radium. In the above calculations the question of heat lost by diffusion and other factors is not taken into consideration, but after allowing a generous margin for error we do not see how more than 1 per cent of the heat required for the hydrothermal action can be ascribed to the radium content of the rock. It is true that a sample of limestone from Mammoth Hot Springs, which Arnold Hague considers typical of the underlying Mesozoic limestones, is more active than the most active of Strutt's sedimentary rocks, ${ }^{b}$ a sample of oolite from the neighborhood of the Bath thermal springs of England, but this coincidence alone is not of sufficient importance to justify a verdict. 




























